\title{
Article \\ Factors Determining the Success of Decision Making and Performance of Portuguese Companies
}

\author{
Albertina Paula Monteiro ${ }^{1}$, Joana Vale ${ }^{2}$ and Amélia Silva ${ }^{1, *(\mathbb{D}}$ \\ 1 Centre for Organizational and Social Studies, Porto Business and Accounting School, Polytechnique of Porto, \\ 4465-004 Matosinhos, Portugal; amonteiro@iscap.ipp.pt \\ 2 Porto Business and Accounting School, Polytechnic of Porto, 4465-004 Matosinhos, Portugal; \\ 2180209@iscap.ipp.pt \\ * Correspondence: acfs@iscap.ipp.pt; Tel.: +351-22-905-0000
}

Citation: Monteiro, Albertina Paula, Joana Vale, and Amélia Silva. 2021. Factors Determining the Success of Decision Making and Performance of Portuguese Companies.

Administrative Sciences 11: 108.

https://doi.org/10.3390/

admsci11040108

Received: 7 July 2021

Accepted: 8 September 2021

Published: 8 October 2021

Publisher's Note: MDPI stays neutral with regard to jurisdictional claims in published maps and institutional affiliations.

Copyright: (c) 2021 by the authors. Licensee MDPI, Basel, Switzerland. This article is an open access article distributed under the terms and conditions of the Creative Commons Attribution (CC BY) license (https:// creativecommons.org/licenses/by/ $4.0 /)$.

\begin{abstract}
This paper empirically examines the impact of the quality of information and control system (the internal control system, the accounting information system, the financial information, and the non-financial information) on decision-making success and business performance. It follows a quantitative approach. An online questionnaire was developed and applied to the managers of Portuguese companies. The evaluation of the theoretical model was performed using the AMOS statistical software and applying the structural equation model technique. Based on 381 observations, the results show that the model variables explain about $30 \%$ and $70 \%$ of the variance of financial and non-financial performance, respectively. This study proves to be relevant not only for the development of the literature, as it evaluates an original and complex model, but also for managers, because it identifies the factors that contribute to the success of Portuguese companies.
\end{abstract}

Keywords: internal control system quality; accounting information system quality; financial information quality; non-financial information quality; decision-making success; business performance

\section{Introduction}

With the development of accounting, it becomes a critical source of information for the owners/managers of companies (Schwartz 2016). There is no doubt that the owners/managers of the companies are those who best understand the entity's objectives (Nguyen and Nguyen 2020) and those who attach greater importance to an efficient information system (Hussin et al. 2002; Azizi Ismail and King 2007; Nguyen and Nguyen 2020). The information system integrates the Accounting Information System (AIS), which enables data to be obtained, recorded, stored, and processed in order to provide useful information (financial and non-financial) to decision-makers (Nguyen and Nguyen 2020).

However, the quality of the AIS, according to Hla and Teru (Hla and Teru 2015), depends on the quality of the Internal Control System (ICS). Literature suggests that the ICS contributes to the quality of financial reporting (Li et al. 2012; Bozzolan and Miihkinen 2019; Rashedi and Dargahi 2019; Bauer et al. 2018) and to the quality of Non-Financial Information (INF) (Bozzolan and Miihkinen 2019; Frazer 2020; Gal and Akisik 2020). On the other hand, these factors prove to be important in the decision-making process (Patel 2015).

Moreover, the quality of AIS and ICS contributes directly and indirectly, through of Financial Information (FI) and INF quality, to Decision Making Success (DMS) (Sajady et al. 2008; Feng et al. 2009; Napitupulu 2018; Le et al. 2019; Han 2019; Ibrahim et al. 2020; Nguyen and Nguyen 2020; Phornlaphatrachakorn 2019; Baugh et al. 2021). Consequently, managers' decisions influence the performance and success of the firm (Pravitasari 2018).

In this sense, for corporate managers to make the best decisions and achieve the desired level of Corporate Performance, namely, financial performance and non-financial 
performance, it is important that they have access to quality of FI and NFI, which in turn implies holding the quality of AIS as well as the quality of ICS.

In Portugal, $99.9 \%$ of the business fabric are micro, small and medium enterprises (Pordata 2019). According to Pordata (2020), the Northern Region of Portugal, in 2018, had the largest number of enterprises $(431,048)$. Although in that year, 61,065 new companies were born in that region (the second highest increase in Portugal), there was the insolvency of 49,526 companies (the highest absolute value of dissolved companies in the national territory). Although the Lisbon Metropolitan Area has 64,421 fewer companies than the North Region, it is the region with the highest number of company births $(66,141)$ and the one with the most companies (596) on national territory (in 2018).

However, since February 2018, the number of new companies has been higher than the number of companies entering insolvency proceedings (INE, Instituto Nacional de Estatística 2020). However, Bertolami et al. (2018) report that many Small and Medium Enterprises (SMEs) do not survive in their first years of life due to a lack of market knowledge, experience in business management and financial problems, given their maturity. However, companies with some maturity also face insolvency processes. Thus, a better understanding of the factors that influence the performance of companies is necessary, as it may contribute to the survival and growth of companies and, consequently, enhance the economic development of the country.

In view of the above, the main objective of this study is to analyze the factors that impact on the DMS and on the performance of Portuguese companies. Specifically, we intend to assess whether: the quality of ICS impacts on the quality of AIS; the quality of ICS and quality of AIS impact on the FI and NFI quality; the quality of FI directly impacts on the quality of NFI, AIS, ICS, FI, and NFI impacts on DMS; the DMS impacts on company performance (financial and Non-Financial Information); and financial performance impacts on Non-Financial Performance.

This study has five sections. The first is devoted to the introduction. Subsequently, the theoretical framework is carried out in the next section, where the main topics are addressed and the research hypotheses are presented. Section 3 refers to the methodology adopted. Sections 4 and 5 explain and discuss the results, as well as the conclusions of this research.

\section{Theoretical Framework and Hypotheses}

Internal Control is a topic that has been around for several decades. Numerous international organizations have tried to define its concept, but without consensus (Gomes 2014). According to the Committee of Sponsoring Organizations of the Treadway Commission (COSO) (COSO 2013, p. 3), internal control is defined as "a process, effected by an entity's board of directors, management and other personnel, designed to provide reasonable assurance regarding the achievement of objectives relating to operations, reporting, and compliance".

However, for Dimitrijevic et al. (2015), internal is an activity that involves financial and management accounting, strategic project, operational and personnel management, as well as total quality management. Thus, Anh et al. (2020, p. 133) mention that IC "does not only control an entity's department but also the process including procedures and regulations intended for all departments to ensure that corporate managers can perform functions of reporting, compliance and operation".

In literature, the terms internal control and ICS are used indiscriminately. However, according to Fachada (2014), the term internal control is often used for concrete actions and ICS for a set of actions designed as a whole. Mirnenko et al. (2020) reinforce the above by defining the ICS as the policies, rules and measures implemented by the manager or person in charge of the company that ensure the proper functioning of the IC and aim at achieving specific company goals, strategies and other objectives.

The main function of ICS is to document economic events and to check their impact on the company's financial situation (Kaplan et al. 1998). For Zeina et al. (2019), ICS should 
provide vital information to reduce uncertainty in decision making and promote better planning and control of business activities. In the same vein, Ibrahim et al. (2020, p. 52) report that ICS is a "vital resource for today's SMEs as it has the ability to facilitate towards an effective decision making, planning and controlling activities of an organisation".

Companies with poor quality of ICS tend to present FI with lower quality, which leads to increased control risk and decreased transparency of information (Phornlaphatrachakorn 2019) and therefore contributes to a decline in trust in financial statements by stakeholders (Asare and Wright 2012).

ICS can promote accurate financial reporting by increasing the quality of FI (Jokipii 2010; Li et al. 2012; Bozzolan and Miihkinen 2019; Rashedi and Dargahi 2019; Frazer 2020; Gal and Akisik 2020; Bauer et al. 2018) NFI (Bozzolan and Miihkinen 2019; Frazer 2020; $\mathrm{Gal}$ and Akisik 2020) and ensuring the enforcement of regulations and laws (Bozzolan and Miihkinen 2019; Frazer 2020). Thus, quality internal control procedures improve the company's information disclosed (Phornlaphatrachakorn 2019; Baugh et al. 2021).

The literature suggests a relationship between ICS's quality and the quality of AIS (Mndzebele 2012). Hla and Teru (2015) report that what determines the quality of AIS is the quality of ICS and the existence of a robust ICS. Susanto (2016) studied the managers and employees of Bandtmg college in Indonesia and obtained the same evidence: the quality of ICS influences the quality of AIS. In this context, the first research hypothesis is formulated:

Hypothesis 1 (H1). The quality of ICS has a positive impact on the quality of AIS.

Schroeder and Shepardson (2016) consider that companies should show sustained improvements in their internal control to obtain better quality financial reports. For Ji et al. (2017), the establishment of high quality of ICS should be seen as an essential mechanism to ensure the quality of FI. Contrary to (Muda et al. 2018; Sari 2018; Leiwakabessy 2020; Triono and Dewi 2020), this statement is supported by several authors such (Feng et al. 2009; Hendri and Amelia 2019; Dewi et al. 2019; Moreno-Enguix et al. 2019; Phornlaphatrachakorn 2019; Dewi and Hoesada 2020; Majid et al. 2020; Wali and Masmoudi 2020; Zebua et al. 2020). Given the above, the second research hypothesis is formulated:

Hypothesis 2 (H2). The quality of ICS has a positive impact on the quality of FI.

The literature evidences an increase in the disclosure of INF by companies. The primary justification for that is the increasing interest of stakeholders in the transparency of the information disclosed by companies (Bennett et al. 2017). Jokipii (2010) mentions that companies have adapted their ICS framework to deal with environmental uncertainty and achieve ICS effectiveness. Indeed, if ICS is successfully applied, it can promote accurate and higher quality financial and non-financial reporting (Bozzolan and Miihkinen 2019; Frazer 2020; Gal and Akisik 2020; Bauer et al. 2018). Moreover, the quality of ICS increases the credibility and authenticity of such information (Frazer 2020). In light of the above arguments, the third research hypothesis is formulated:

Hypothesis 3 (H3). The quality of ICS has a positive impact on the quality of NFI.

Fitriati and Susanto (2017) analyze whether the ICS contributes to the quality of FI and perceive that the improvement of this variable depends on the quality of ICS of the company. Other authors highlight the same findings, i.e., that the quality of AIS influences the quality of FI, such as (Sajady et al. 2008; Salehi et al. 2010; Zeina et al. 2016; Muda et al. 2018; Majid et al. 2020). However, Leiwakabessy (2020) does not evidence the same findings. Against this background, the fourth research hypothesis is formulated:

Hypothesis 4 (H4). The quality of AIS has a positive impact on the quality of FI. 
The AIS should prepare FI and NFI. The last decades have seen an increasing number of studies in NFI preparation and dissemination (Al-Wattar et al. 2019; Petcharat and Mula 2009; Zyznarska-Dworczak 2018; Mohammed Al-Shafeay and Almagtome 2019; Arroyo and HEC Montreal 2008).

Petcharat and Mula (2009) mention the importance of a Sustainability Management Accounting Information System (SMAS), since it allows the preparing and disseminating of more complete information for better decision-making. Arroyo and HEC Montreal (2008) mention that SMAS should simultaneously provide economic, environmental and social information. Zyznarska-Dworczak (2018) adds that SMAS should ensure the transparency of ICS data, related to Corporate Social Responsibility (CSR), which increases the credibility of CSR reporting as it improves the quality of NFI.

However, Al-Wattar et al. (2019) consider that the current AIS does not fully meet the requirements of NFI reporting, as it mainly contributes to the provision of financial sustainability indicators. However, the authors mention that the integration in the AIS of the three pillars of sustainability will inevitably allow changing the management vision and improving the level of disclosure (FI and NFI) and the quality of business information as a whole. In this context, the fifth research hypothesis is formulated:

Hypothesis 5 (H5). The quality of AIS has a positive impact on the quality of NFI.

Flöstrand (2006) reports that the Reports and Accounts include mainly FI. Thus, according to the authors, if companies intend to increase information disclosure (Report and Accounts or other reports available to stakeholders), they should also incorporate NFI. In this context, Verrecchia (1990) indicates that companies, when disclosing FI with quality have reasons to provide more information of a non-financial nature.

Martínez-Ferrero et al. (2013), in turn, mention that companies that provide FI with quality tend to be more conservative. Thus, these are less likely to carry out unethical practices, such as earnings management practices, making them more socially responsible. Therefore, according to the results of the authors' study, companies that disclose high-quality FI also tend to report high-quality NFI. Thus, the sixth research hypothesis is formulated:

Hypothesis 6 (H6). The quality of FI has a positive impact on the quality of NFI.

According to Menicucci (2020), the FI should gather qualitative features to become useful in decision-making. Ježovita (2015), when analyzing 320 Croatian companies, concludes that the information available in the reports and accounts is essential in the decision-making process. Dewi et al. (2019) also evidenced this when analyzing 161 out of 303 individuals of the Agency (Dinas) belonging to the Government of South Sumatra Province (Indonesia). Thus, decision-making based on FI, which brings together qualitative characteristics, can determine DMS. In the same vein, Malo-Alain et al. (2019) state that the absence of QFI can jeopardize DMS. Given the context, the seventh research hypothesis is formulated:

Hypothesis 7 (H7). The quality of FI has a positive impact on DMS.

Barker and Eccles (2018) report that NFI is not recognized in financial statements. However, Raucci et al. (2020) note that after the introduction of legislation regarding mandatory disclosure of NFI (for certain companies and depending on the country), companies started to disclose only the indicators they consider most "relevant" under Directive 2014/95/EU.

According to Mbabazise et al. (2015), NFI plays a vital role in decision making when related to market participation, quality management and environmental protection. Thus, literature suggests that NFI is important and determines DMS (Boulianne 2007; Barker and Eccles 2018), which leads to formulating the eighth research hypothesis in this study: 
Hypothesis 8 (H8). The quality of NFI has a positive impact on DMS.

Do and Dinh (2020) report that financial managers need information prepared and provided by the GIS, to be able to assess past performance and make future plans. Sajady et al. (2008) find that a firm's AIS quality contributes to the quality of FI and better decisions. Evidence, this is also corroborated by Ibrahim et al. (2020). As a vital resource in SMEs, ICS can facilitate decision-making, planning, and control of company activities. Nguyen and Nguyen (2020) also find that the existence of the quality of AIS positively influences the effectiveness of decision-making. In this context, the ninth research hypothesis of this study is formulated:

Hypothesis 9 (H9). The quality of AIS contributes positively to DMS.

Phornlaphatrachakorn (2019) finds that the quality of ICS positively affects DMS in canned and processed food firms in Thailand. Feng et al. (2009) evidence that poor quality of ICS affects managers' decisions related to production, capital investment, mergers and acquisitions, research and development, advertising, and hiring or expanding the entity. Thus, improving ICS's quality can effectively enhance the efficiency of decision-making and, therefore, determine its success (Han 2019). Since the quality of ICS is a determinant of DMS, the tenth research hypothesis is formulated in this study:

Hypothesis 10 (H10). The quality of ICS contributes positively to DMS.

Pravitasari (2018) points out that managers' decisions have significant consequences on firm performance and success. Incidentally, (Bosworth 2005; Patel 2015; Phornlaphatrachakorn 2019) maintain that effective and efficient decision-making will ultimately positively affect the profitability of the firm, i.e., its Financial Performance. In view of this, in this study, the following research hypothesis is defined:

Hypothesis 11 (H11). DMS contributes positively to Financial Performance.

The continuous increase in awareness of the impact of human activities on the environment and its well-being has promoted a greater sense of responsibility (Harding 1998). However, according to Martos et al. (2016), the adoption of mechanisms aimed at promoting sustainable development is an issue that involves all stakeholders and not only company managers.

According to Zhang (2014), managers of North American industrial companies can develop systemic approaches to improve the well-being of their employees, energy efficiency, as well as to obtain a more efficient and sustained production and, consequently, obtain superior performance at the financial and non-financial level. The literature suggests that the appropriate and strategic inclusion of the feeling of (social and environmental) responsiveness can determine the success of decision making and therefore potently influence financial and Non-Financial Performance (Harding 1998; Zhang 2014; Pravitasari 2018). Given this framework, the penultimate research hypothesis is formulated:

Hypothesis 12 (H12). DMS contributes positively to Non-Financial Performance.

As mentioned above, several authors analyze the relationship between the two concepts of company performance (Financial Performance and Non-Financial Performance). Chen et al. (2018) demonstrate a positive relationship between Financial Performance and Non-Financial Performance. In this context, the last research hypothesis is formulated:

Hypothesis 13 (H13). Financial Performance contributes positively to Non-Financial Performance. 
As can be seen in the proposed conceptual model (Figure 1), the specific research objectives give rise to 13 hypotheses.

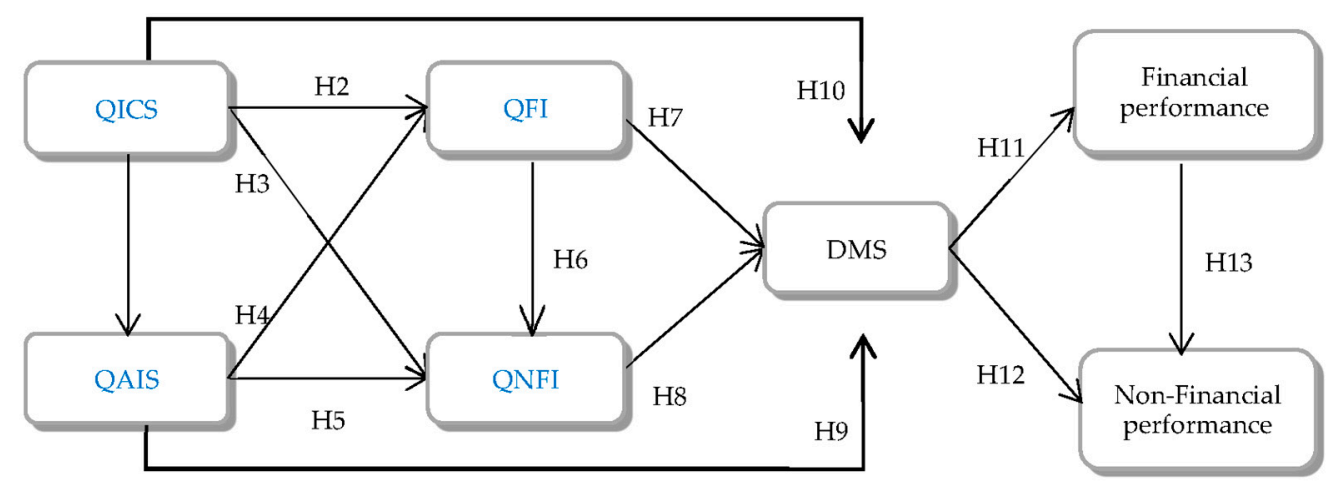

Legend: QICS - Quality of ICS; QAIS - Quality of AIS; QFI - Quality of FI; QNFI - Quality of NFI

Figure 1. Conceptual model. Legend: QICS—Quality of ICS; QAIS—Quality of AIS; QFI—Quality of FI; QNFI—Quality of NFI.

\section{Methodology}

The operationalization of this investigation is based on quantitative research. A survey, by questionnaire, was addressed to the managers of Portuguese companies. The questionnaire was prepared using the Lime Survey software.

Regarding the survey structure, it is divided into 8 parts. The first two parts include questions about the respondent's and company's characterization. Regarding the remaining six parts, these include items that allow assessing each of the dimensions under study. In this study, we used validated measurement scales or scales adapted from previous studies, and the ordering of answers for each item/statement of the variables/dimensions highlighted in the proposed conceptual model follows a 5-point Likert scale where 1 corresponds to "strongly disagree" and 5 corresponds to "strongly agree".

Regarding the items used to measure the quality of ICS, these are mostly obtained/ adapted from the study by Phornlaphatrachakorn (2019). Only one item results from the pre-test of questionnaire ("The company's internal control system has quality"). The items that allow to assess the quality of AIS were obtained/adapted from Soudani (2012) and from Kpurugbara et al. (2016). Only one item resulted from the pre-test of questionnaire ("The company's accounting information system works efficiently and effectively"). The quality of FI dimension was measured using the measurement scale adapted from Dornier (2018). The follow items resulted from the pre-test of questionnaire ("Financial information represents in a reliable way what you want to portray; "Financial information is free of value judgments"). As regards the quality of NFI construct, this study uses items adjusted to NFI. In this way, we use items adapted from Dornier (2018) and a result of the pre-test of questionnaire ("Non-financial information is free of value judgements"). Regarding the DMS, this dimension follows the measurement scale used by Phornlaphatrachakorn (2019). Only one item was added that derives from the pre-test of questionnaire ("The decisions made in the company determine its success"). Finally, in assessing Financial Performance we essentially follow the measurement scale used by Trailer et al. (1996). The Non-Financial Performance measurement scale is adapted from Soudani (2012). The items "The company's financial performance has been successful" and "The company's (nonfinancial) performance has been successful" resulted from the pre-test of questionnaire for the dimensions Financial Performance and Non-Financial Performance, respectively. In the Appendix A are described the measurement scales used in this study.

The selection process of the sampling was carried out on the SABI database, applying the following 5 filters: (1) all companies with an e-mail address (Portugal); (2) last number of employees: minimum 50; (3) companies with an audit; (4) companies, whose legal form is: sole proprietorship, foreign entity, joint-stock company, limited partnership, limited company, and limited liability company by a sole owner; and (5) active companies. 
The SABI database generated a list of 7812 Portuguese companies. Despite being a substantial number, it was decided to apply the survey to all companies instead of limiting the study to one region or district of the country. This option was made because this study is applied to company managers and there is a likelihood of obtaining a low response rate.

The survey was applied online. The link to it was sent by email to the companies and addressed to the person who makes the main decisions in the companies (managers). In the period from 2 to 31 March 2020 emails were sent to 7812 companies, 13 of which have been returned. During the mentioned period, 389 observations were obtained. However, 8 observations were eliminated for not being complete. Thus, the final sample consists of 381 observations. Given the high number of Portuguese companies, the option was for a non-probabilistic sample, a practice used in scientific studies that cover a large population (Cepêda and Monteiro 2020; Montenegro and Rodrigues 2020). Researchers used this method because it was impossible to draw random probability sampling due to time or cost considerations. Moreover, studies involving this population are usually based in non-probabilistic sample.

Data analysis encompasses three phases: (1) preliminary data analysis, (2) the assessment of the measurement model, and (3) the assessment of the structural model.

\section{Results}

\subsection{Assessment of the Measurement Model}

The assessment of the measurement model was carried out in the AMOS statistical software. The assessment of the measurement model involves the use of confirmatory factor analysis for each dimension under study, individually. The measurement scale was reduced until the model with adequate fit. This kind of analysis consists in assessing the measures unidimensionality, the reliability, and the validity of the constructs.

To assess the suitability of the measurement scales, the measures' unidimensionality, the validity (convergent and discriminant), and the reliability of the constructs incorporated in the proposed theoretical model are evaluated. Table 1 shows these indicators and, by analysing it, the items report significantly to the respective factor/construct, thus highlighting the unidimensionality of the dimensions under analysis (Fornell and Larcker 1981; Steenkamp and van Trijp 1991; Marôco 2010).

Table 1. Confirmatory factor analysis results.

\begin{tabular}{|c|c|}
\hline Construct & c.s. \\
\hline \multicolumn{2}{|l|}{ Quality of ICS $(\mathrm{CR}=0.93, \mathrm{AVE}=0.66)$} \\
\hline $\begin{array}{l}\text { 1QICS-Internal control system has improved and promoted the company's } \\
\text { operational efficiency and effectiveness. }\end{array}$ & 0.904 * \\
\hline $\begin{array}{l}\text { 3QICS-Internal control system has allowed building and creating effective operations, } \\
\text { activity, and business practices. }\end{array}$ & 0.834 * \\
\hline $\begin{array}{l}\text { 4QICS-Internal control system has allowed the company to prepare financial } \\
\text { information with quality. }\end{array}$ & 0.824 * \\
\hline $\begin{array}{l}\text { 6QICS-The company complies with all required regulations, i.e., laws, rules, } \\
\text { guidelines, standards, and other related issues within internal control quality. }\end{array}$ & 0.667 * \\
\hline \multicolumn{2}{|l|}{ Quality of AIS $(\mathrm{CR}=0.92, \mathrm{AVE}=0.61)$} \\
\hline $\begin{array}{l}\text { 5QAIS - The data processing caused the improvement of the quality of the } \\
\text { financial reports. }\end{array}$ & 0.864 * \\
\hline $\begin{array}{l}\text { 6QAIS-The automated data collection speed up the process of non-financial } \\
\text { information preparation }\end{array}$ & $0.758 *$ \\
\hline $\begin{array}{l}\text { 7QAIS - The automated data collection speed up the process to generate financial } \\
\text { statements and overcome human weaknesses in data processing. }\end{array}$ & 0.744 * \\
\hline
\end{tabular}


Table 1. Cont.

\begin{tabular}{|c|c|}
\hline Construct & c.s. \\
\hline $\begin{array}{l}\text { 8QAIS-The automated data collection provides a platform with access to information, } \\
\text { which facilitates the use of it. }\end{array}$ & $0.752 *$ \\
\hline \multicolumn{2}{|l|}{ Quality of FI $(\mathrm{CR}=0.90, \mathrm{AVE}=0.56)$} \\
\hline 2QFI-The accuracy of financial information helps decision-making. & 0.724 * \\
\hline 3QFI-Financial information is carefully prepared to ensure its reliability. & 0.831 * \\
\hline 5QFI-Financial information is easily understood by its user. & 0.719 * \\
\hline 8QFI-Financial information represents in a reliable way what you want to portray. & 0.723 * \\
\hline \multicolumn{2}{|l|}{ Quality of Non-Financial Information $(\mathrm{CR}=0.91, \mathrm{AVE}=0.60)$} \\
\hline 2QNFI-Non-financial information is carefully prepared to ensure its quality. & 0.804 * \\
\hline 3QNFI-Non-financial information is easily understood by its user. & $0.846^{*}$ \\
\hline $\begin{array}{l}\text { 4QNFI-Non-financial information includes all the information necessary to } \\
\text { make decisions. }\end{array}$ & 0.735 * \\
\hline 5QNFI-Non-financial information is free of value judgements. & 0.701 * \\
\hline \multicolumn{2}{|l|}{ DMS $(\mathrm{CR}=0.95, \mathrm{AVE}=0.73)$} \\
\hline $\begin{array}{l}\text { 1DMS-The decisions made allowed the company to achieve advantages in terms of } \\
\text { operations, management, and performance. }\end{array}$ & 0.857 * \\
\hline $\begin{array}{l}\text { 2DMS-Decisions made about investments took into account different alternatives or } \\
\text { options, which allowed the company to choose the best solution. }\end{array}$ & 0.837 * \\
\hline $\begin{array}{l}\text { 4DMS The decisions taken have contributed to maximized operational efficiency } \\
\text { and effectiveness. }\end{array}$ & 0.910 * \\
\hline 5DMS The decisions made in the company determine its success. & 0.764 * \\
\hline \multicolumn{2}{|l|}{ Performance } \\
\hline \multicolumn{2}{|l|}{ Financial Performance $(\mathrm{CR}=0.948, \mathrm{AVE}=0.733)$} \\
\hline $2 \mathrm{FP}-$ The size of the company has increased. & 0.597 * \\
\hline 4FP-The company's operating profit has improved/increased. & 0.881 * \\
\hline 6FP—Return on equity improved/increased (EBIT/Equity). & 0.967 * \\
\hline 7FP_Profitability on sales increased (EBIT/Sales). & 0.930 * \\
\hline \multicolumn{2}{|l|}{ Non-Financial Performance $(\mathrm{CR}=0.928, \mathrm{AVE}=0.645)$} \\
\hline 9NFP-The company has improved its customer service. & $0.792 *$ \\
\hline $\begin{array}{l}\text { 10NFP-The company has improved working conditions, regardless of the } \\
\text { employee's position. }\end{array}$ & 0.850 * \\
\hline $\begin{array}{l}\text { 11NFP-The company has improved its performance in terms of social responsibility } \\
\text { (voluntary effort on the part of the company in the creation of various measures to meet } \\
\text { the expectations of the different interested parties—-stakeholders). }\end{array}$ & $0.842 *$ \\
\hline 13NFP_The company has increased its employee retention rates. & 0.721 * \\
\hline
\end{tabular}

Regarding reliability measured by the composite reliability (CR), it was found that all constructs have a value greater than 0.70 , which proves the reliability of the model (Marôco 2010). As the values of the standardized coefficients of each construct are greater than 0.50, it is conferred convergent validity (Steenkamp and van Trijp 1991). Finally, it should be highlighted that the model also presents discriminant validity, given that the average variance extracted (AVE) of each construct is greater than 0.50 (Fornell and Larcker 1981). 


\subsection{Assessment of the Structural Model}

This section will evaluate the proposed theoretical model and test the research hypotheses formulated in this study (H1-H13). In this type of investigation, techniques should be used that allow to improve the adjustment of the initially proposed model, the results of the initial and theoretical model are presented below.

\subsubsection{Assessment of the Initial Structural Model}

By analysing fit indexes (Table 2) it is possible to conclude that the initial theoretical model has a good fit (RMSEA < 0.05), and all the other fit measures also reveal a good fit (Marôco 2010; Hair et al. 1998).

Table 2. Overall fit measures for the initial structural model.

\begin{tabular}{ccccc}
\hline \multicolumn{5}{c}{ Fit Measure } \\
\hline$X^{2} /$ gl & RMSEA & GFI & NFI & CFI \\
\hline 1.813 & 0.046 & 0.902 & 0.926 & 0.965 \\
\hline$<3$ & $<0.05$ & $>0.90$ & $>0.90$ & $>0.90$ \\
\hline Good fit (Hair et al. 1998). & & &
\end{tabular}

Figure 2 presents the results of the evaluation of the initial model (with standardized coefficients). The outputs, regarding the modification indices (generated in the AMOS software), suggest the addition of error covariance between items. This is a standard procedure that allows improving the quality of model fit by solving some unidimensionality problems (Baumgartner and Homburg 1996; Ping 2004). Thus, error covariances were added, as shown in the figure below.

The results of the structural model analysis indicate that there is no significant relationship between the quality of AIS and quality of FI, quality of ICS and quality of NFI, quality of AIS and quality of NFI, QFI and DMS, quality of NFI and DMS, and quality of AIS and DMS, given $p>0.05$ (Table 3 ).

Table 3. Results of the assessment of the initial theoretical model.

\begin{tabular}{|c|c|c|c|c|c|c|}
\hline \multicolumn{3}{|c|}{ Parameters } & \multirow{2}{*}{$\begin{array}{c}\text { Non-Standardised } \\
\text { Coefficient }\end{array}$} & \multirow{2}{*}{$\begin{array}{c}\begin{array}{c}\text { Standardised } \\
\text { Coefficient }\end{array} \\
0.552\end{array}$} & \multirow{2}{*}{$\frac{p \text {-Value }}{* * *}$} & \multirow{2}{*}{$\begin{array}{l}\mathbf{R}^{\mathbf{2}} \\
0.30\end{array}$} \\
\hline QICS & - & QAIS & & & & \\
\hline QICS & - & QFI & 0.818 & 0.794 & $* * *$ & \multirow{2}{*}{0.73} \\
\hline QAIS & - & QFI & 0.093 & 0.105 & 0.082 & \\
\hline QICS & - & QNFI & 0.208 & 0.178 & 0.157 & \multirow{3}{*}{0.56} \\
\hline QAIS & - & QNFI & 0.033 & 0.033 & 0.574 & \\
\hline QFI & - & QNFI & 0.651 & 0.575 & $* * *$ & \\
\hline QFI & - & DMS & -0.063 & -0.068 & 0.636 & \multirow{4}{*}{0.71} \\
\hline QNFI & - & DMS & 0.111 & 0.136 & 0.057 & \\
\hline QAIS & - & DMS & -0.008 & -0.01 & 0.858 & \\
\hline QICS & - & DMS & 0.767 & 0.807 & $* * *$ & \\
\hline DMS & - & $\mathrm{FP}$ & 0.663 & 0.55 & $* * *$ & 0.30 \\
\hline DMS & - & NFP & 0.737 & 0.509 & $* * *$ & \multirow{2}{*}{0.68} \\
\hline $\mathrm{FP}$ & - & NFP & 0.509 & 0.424 & $* * *$ & \\
\hline
\end{tabular}

Notes: $\mathrm{R}^{2}$ —coefficient of determination; ${ }^{* * *}$ significant value for 0.001 . QICS—Quality of ICS; QAIS—Quality of AIS; QFI—Quality of FI; QNFI—Quality of NFI; DMS—Decision Making Decision; FP—Financial Performance; NFP-Non-Financial Performance.

Next, the structural model is revised in order to eliminate the relationships that show the absence of statistical significance. 


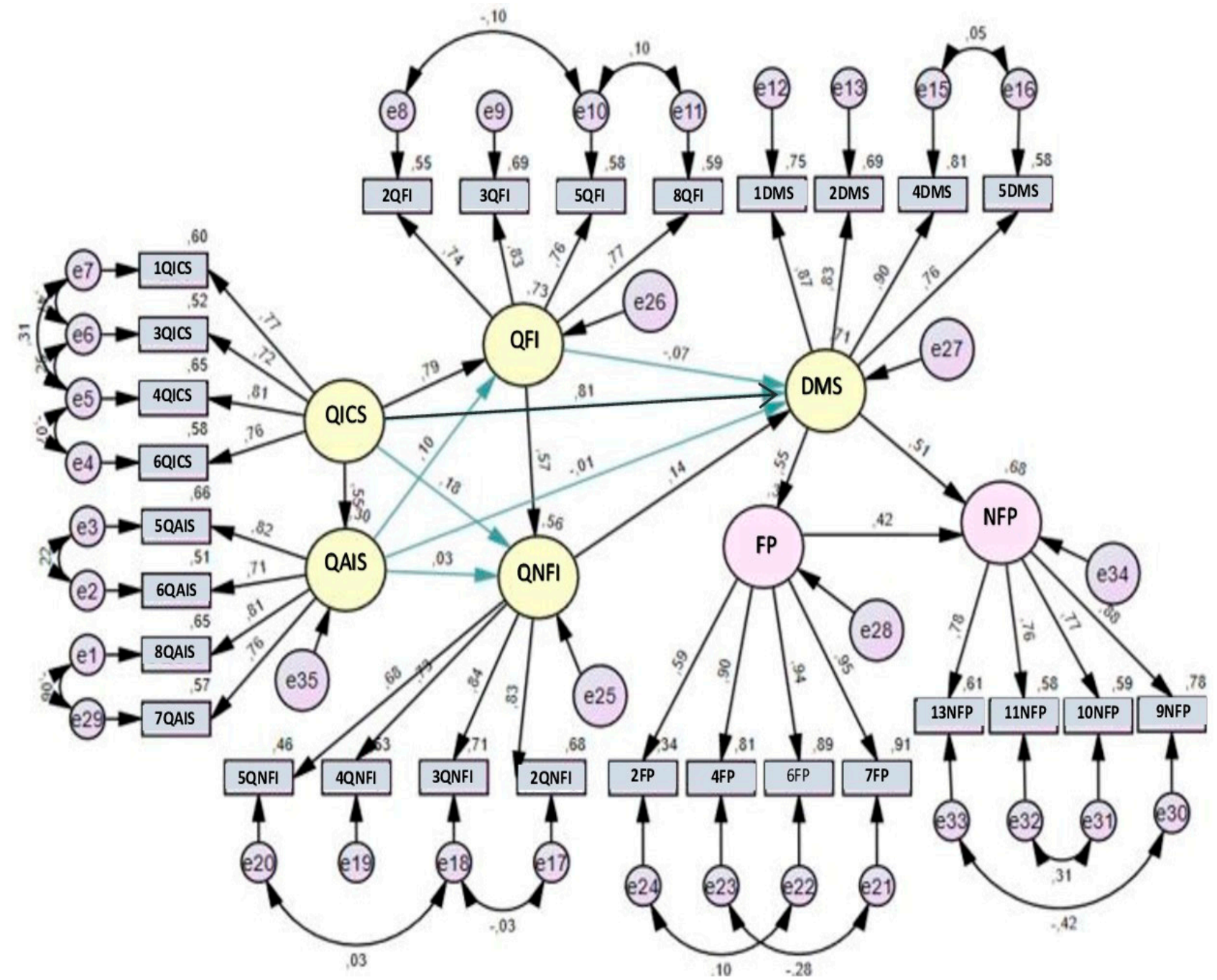

Figure 2. Path diagram of the initial theoretical model. Legend: QICS—Quality of ICS; QAIS — Quality of AIS; QFI—Quality of FI; QNFI—Quality of NFI; DMS—Decision Making Decision; FP—Financial Performance; NFP—Non-Financial Performance.

\subsubsection{Assessment of the Revised Theoretical Model}

The initial theoretical model was revised. The results have a significant relationship, except for the relationship between quality of AIS and quality of FI and between quality of NFI and DMS. Thus, the model is now found with all positive and significant causal relationships $(p<0.01)$. This model revealed a slight improvement in the fit measures. Therefore, the values of the fit indexes indicate a good fit of the revised model $($ RMSEA $=0.045$, GFI $=0.904, \mathrm{NFI}=0.926, \mathrm{CFI}=0.966$ (Hair et al. 1998; Marôco 2010). This model has the same added error covariances as the initial model, which also revealed a slight improvement in the measures of adjustment (Figure 3).

Table 4 presents the results of the assessment of the revised structural model.

Therefore, by observing the coefficient of determination, 6 evidence are obtained: (1) quality of ICS explains $28.4 \%$ of the quality of AIS variance; (2) quality of ICS and quality of AIS explain $69.7 \%$ of the quality of FI variance; (3) quality of ICS, quality of AIS and quality of FI explain $57.6 \%$ of the quality of NFI variance; (4) quality of ICS, quality of AIS, quality of FI and Quality of NFI together explain $65 \%$ of the DMS variance; (5) quality of ICS, AIS, FI, NFI, and DMS explain $29.3 \%$ of the Financial Performance variance; and (6) this one, together with the other variables, explain $69.7 \%$ of the NonFinancial Performance variance. 


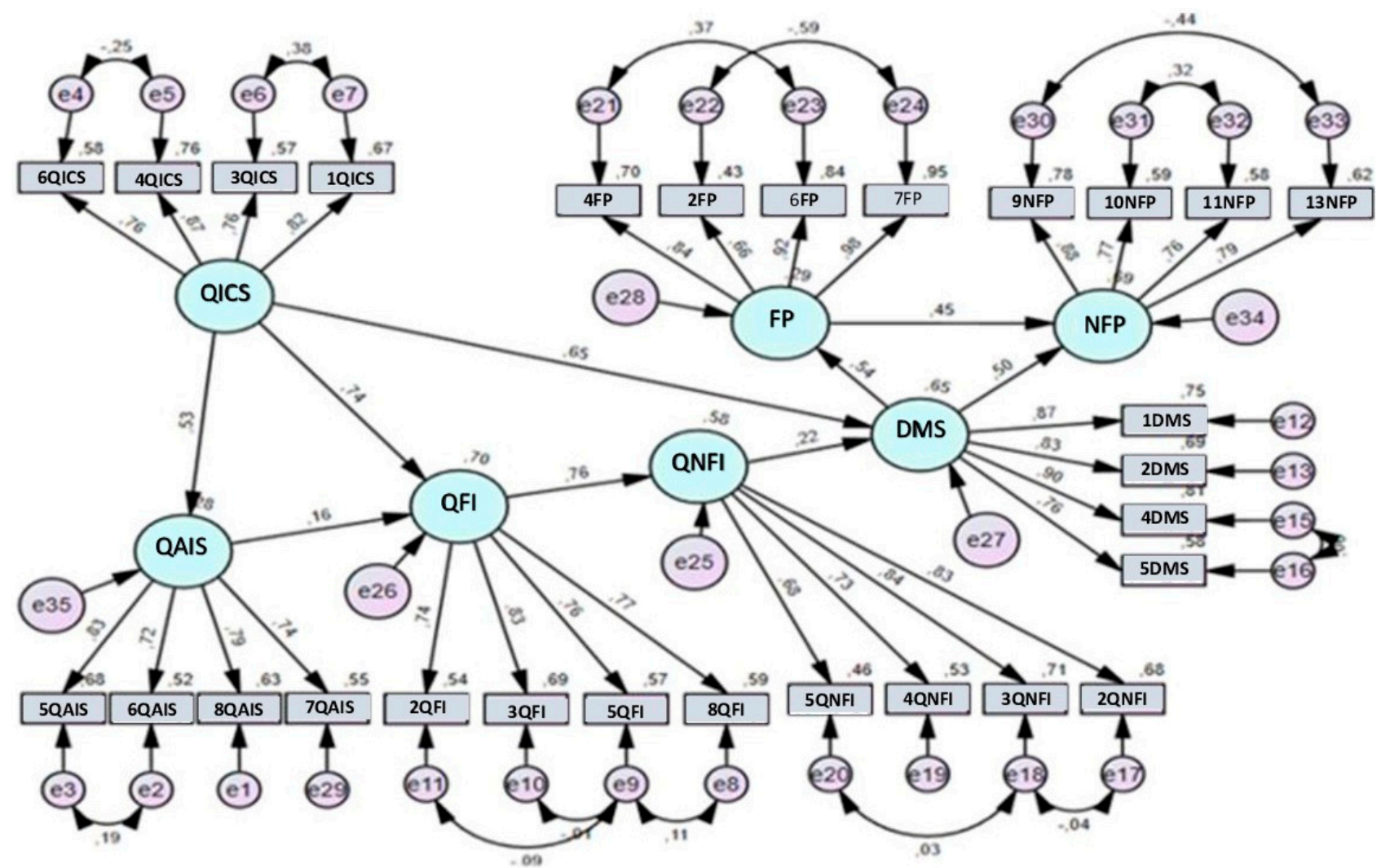

Figure 3. Path diagram of the revised theoretical model. Legend: QICS—Quality of ICS; QAIS—Quality of AIS; QFI—Quality of FI; QNFI—Quality of NFI; DMS—Decision Making Decision; FP—Financial Performance; NFP—Non-Financial Performance.

Table 4. Results of the assessment of the revised theoretical model.

\begin{tabular}{|c|c|c|c|c|c|c|c|}
\hline Hypothesis & & Parameters & & $\begin{array}{c}\text { Non-Standardised } \\
\text { Coefficient }\end{array}$ & $\begin{array}{l}\text { Standardised } \\
\text { Coefficient }\end{array}$ & $p$-Value & $\mathbf{R}^{2}$ \\
\hline $\mathrm{H} 1$ & QICS & - & QAIS & 0.611 & 0.533 & $* * *$ & 0.284 \\
\hline $\mathrm{H} 2$ & QICS & - & QFI & 0.711 & 0.74 & $* * *$ & \multirow{2}{*}{0.697} \\
\hline $\mathrm{H} 4$ & QAIS & - & QFI & 0.133 & 0.158 & 0.002 * & \\
\hline H6 & QFI & - & QNFI & 0.92 & 0.759 & $* * *$ & 0.576 \\
\hline H8 & QNFI & - & DMS & 0.175 & 0.216 & $* * *$ & \multirow{2}{*}{0.650} \\
\hline H10 & QICS & - & DMS & 0.618 & 0.654 & $* * *$ & \\
\hline H11 & DMS & - & $\mathrm{FP}$ & 1.019 & 0.541 & $* * *$ & 0.293 \\
\hline H12 & DMS & - & NFP & 0.728 & 0.498 & $* * *$ & \multirow{2}{*}{0.697} \\
\hline H13 & $\mathrm{FP}$ & - & NFP & 0.348 & 0.449 & $* * *$ & \\
\hline
\end{tabular}

Notes: $\mathrm{R}^{2}$ : coefficient of determination; ${ }^{* * *}$ significant value for $0.001 ;{ }^{*}$ significant value for 0.01 . QICS-Quality of ICS; QAIS-Quality of AIS; QFI-Quality of FI; QNFI-Quality of NFI; DMS—Decision Making Decision; FP-Financial Performance; NFP-Non-Financial Performance. From the analysis of Table 4, it is verified that all the hypotheses now tested are supported $(p$-value $<0.01)$. Thus, there are 9 supported hypotheses and 4 rejected (H3, H5, H7 and H9).

\subsubsection{Assessment of the Direct, Indirect, and Total Effects}

Additionally, this study evaluates the direct, indirect, and total effects. The analysis of the structural model generates the direct effects established in the proposed theoretical model. However, it is also important to assess the indirect and total effects of the variables.

Thus, Table 5 presents the direct, indirect and, total effects between the constructs (obtained in the AMOS software). 
Table 5. Direct, indirect, and total effects.

\begin{tabular}{|c|c|c|c|}
\hline & Direct & Indirect & Total \\
\hline \multicolumn{4}{|l|}{ Effects on QAIS } \\
\hline QICS-QAIS & 0.53 & & 0.533 \\
\hline \multicolumn{4}{|l|}{ Effects on QFI } \\
\hline QICS-QAIS-QFI & & 0.084 & \multirow{2}{*}{0.824} \\
\hline QICS-QFI & 0.74 & & \\
\hline \multicolumn{4}{|l|}{ Effects on QNFI } \\
\hline QICS-QAIS-QFI-QNFI & & 0.064 & \multirow{2}{*}{0.626} \\
\hline QICS-QFI-QNFI & & 0.562 & \\
\hline \multicolumn{4}{|l|}{ Effects on DMS } \\
\hline QICS-QAIS-QFI-QNFI-DMS & & 0.014 & \multirow{3}{*}{0.789} \\
\hline QICS-QFI-QNFI-DMS & & 0.121 & \\
\hline QICS-DMS & 0.654 & & \\
\hline \multicolumn{4}{|l|}{ Effects on FP } \\
\hline QICS-QAIS-QFI-QNFI-DMS-FP & & 0.007 & \multirow{3}{*}{0.427} \\
\hline QICS-QFI-QNFI-DMS-FP & & 0.066 & \\
\hline QICS-DMS-FP & & 0.354 & \\
\hline \multicolumn{4}{|l|}{ Effects on NFP } \\
\hline QICS-QAIS-QFI-QNFI-DMS-FP-NFP & & 0.003 & \multirow{6}{*}{0.584} \\
\hline QICS-QAIS-QFI-QNFI-DMS- NFP & & 0.007 & \\
\hline QICS-QFI-QNFI-DMS- FP-NFP & & 0.060 & \\
\hline QICS-QFI-QNFI-DMS-NFP & & 0.029 & \\
\hline QICS-DMS-FP-NFP & & 0.159 & \\
\hline QICS-DMS-NFP & & 0.326 & \\
\hline
\end{tabular}

Legend: QICS—Quality of ICS; QAIS—Quality of AIS; QFI—Quality of FI; QNFI—Quality of NFI; DMS—Decision Making Decision; FP-Financial Performance; NFP-Non-Financial Performance.

Regarding the effect on the quality of the AIS variable, it can be seen by observing the revised model that this only presents a direct relationship with the quality of ICS variable. Thus, the direct effect corresponds to the total effect (0.533).

The total effect on the quality of FI variable results from the direct effect of the quality of ICS of 0.74 and the indirect effect (QICS-QAIS-QFI) of 0.084, which corresponds to a total effect of 0.824 .

As regards the quality of NFI, the total effect (0.626) results from indirect effects from the relationship between QICS-QAIS-QFI-QNFI and the relationship between QICS-QFIQNFI, of 0.064 and 0.562 , respectively.

The total effect of the DMS variable (0.789) is influenced by the direct effect of the quality of ICS (0.654) and the indirect effects of the QICS-QAIS-QFI-QNFI-DMS and QICS-QFI-QNFI-DMS relationships, of 0.014 and 0.121 , respectively.

The FP is influenced by the indirect effects (QICS-QAIS-QFI-QNFI-DMS-FP; QICSQFI-QNFI-DMS-FP and QICS-DMS-FP), which corresponds to a total effect of 0.427. Table 5 .

The total effect on quality of NFP (0.584) results from six indirect effects presented on

Next, the mediating effects of the variables are analyzed, which present themselves in this quality. 


\subsubsection{Analysis of the Mediating Effect}

Regarding the relationship between the quality of ICS and quality of FI, the quality of ICS has a direct effect of 0.533 on the quality of AIS and the last one has an effect of 0.158 on the quality of FI. Therefore, the indirect effect of quality of ICS on quality of FI through the quality of AIS is $0.084(0.533 \times 0.158)$ and significant $(p$-value $<0.01)$. Thus, the quality of AIS presents itself as a mediating variable in the relationship between quality of ICS and the quality of FI.

The results show that both the quality of ICS and quality of AIS do not have a direct impact on the quality of NFI in the initial model. However, both variables present an indirect effect on the quality of NFI through the quality of FI (QICS-QFI-QNFI; QAIS-QFIQNFI). Since the quality of ICS has a direct effect of 0.74 on the quality of FI and this one has an effect of 0.759 on the quality of NFI, the indirect effect of quality of ICS on quality of NFI through quality of FI is $0.562(0.74 \times 0.759)$ and significant $(p$-value $<0.001)$ on the three applied tests. In turn, quality of AIS has a direct effect of 0.158 on quality of FI and 0.759 on quality of NFI, so the indirect effect of quality of AIS on quality of NFI through quality of FI is $0.12(0.158 \times 0.759)$ and significant $(p$-value $<0.01)$. Therefore, the quality of FI presents itself as a mediating variable in the relationship between the quality of ICS/AIS and the quality of NFI.

Another evidenced result is that the quality of FI also does not have a direct relationship with the DMS (initial model). However, the test for mediating effects shows an indirect relationship through the quality of NFI. The quality of FI presents a direct effect of 0.759 on quality of NFI and quality of NFI has an effect of 0.216 on DMS, thus, highlighting an indirect effect of quality of FI on DMS through quality of NFI of $0.164(0.759 \times 0.216)$ and significant $(p$-value $<0.001)$. Therefore, quality of NFI presents itself as a mediating variable in the relationship between quality of FI and DMS.

Although the direct relationship of both quality of ICS and quality of NFI on Financial Performance has not been studied, both (QICS and QNFI) show an indirect relationship through DMS (QICS-DMS-FP; QNFI-DMS-FP). This is because quality of ICS has a direct effect of 0.654 on DMS and 0.541 on FP. Thus, the indirect effect of quality of ICS on Financial Performance through DMS is $0.354(0.654 \times 0.541)$ and significant $(p$-value $<0.001)$. Regarding quality of NFI, it presents a direct effect of 0.216 on DMS and this one an effect of 0.541 on Financial Performance; therefore, the indirect effect of quality of AIS on Financial Performance through DMS is $0.117(0.216 \times 0.541)$ and significant $(p$-value $<0.001)$ in the three applied tests. Therefore, the DMS presents itself as a mediating variable in the relationship between quality of ICS/NFI and the Financial Performance.

As regards the indirect effect on Non-Financial Performance, it is possible to analyze three effects (QICS-DMS-NFP; QNFI-DMS-NFP; and DMS-FP-NFP). The results reveal that (1) both quality of ICS and quality of NFI present an indirect relationship with NonFinancial Information, through DMS, and (2) although DMS has a direct relationship on Non-Financial Information, it also presents an indirect relationship through Financial Performance. This is because quality of ICS presents a direct effect of 0.654 on DMS and DMS has an effect of 0.498 on Non-Financial Information, so the indirect effect of quality of ICS on Non-Financial Information through DMS is $0.326(0.654 \times 0.498)$ and significant ( $p$-value $<0.001$ ). Regarding quality of NFI, it presents a direct effect of 0.216 on DMS and 0.498 on Non-Financial Information; therefore, the indirect effect of quality of NFI on Non-Financial Information through DMS is $0.108(0.216 \times 0.498)$ and significant $(p$-value $<0.01)$ in the three applied tests. Finally, DMS presents a direct effect of 0.541 on Financial Performance and an effect of 0.449 on Non-Financial Information; thus, the indirect effect of DMS on Non-Financial Information through Financial Performance is $0.243(0.541 \times 0.449)$ and significant $(p$-value $<0.01)$. Therefore, DMS is a mediating variable in the relationship between quality of ICS/NFI and quality of Non-Financial Information, and Financial Performance is a mediating variable in the relationship between DMS and Non-Financial Performance. 


\section{Discussion of Results}

The results suggest that quality of ICS has a positive and significant effect on quality of AIS ( $\beta=0.533 ; p$-value $<0.001$ ), which allows one to conclude that the improving quality of ICS contributes to the improvement of quality of AIS, and that the first variable explains $28.4 \%$ of the second. Thus, this study supports H1. Therefore, the results of this study are in line with those verified by Susanto (2016). This author verifies that the quality of ICS has a positive and significant relationship on quality of AIS, and that the first variable has a $25 \%$ influence on the second. However, Anggadini (2015) verifies that top management supports and ICS significantly influence quality of AIS, with a coefficient of determination of 0.72 .

As for the relationship between the quality of ICS and quality of FI dimensions, it is positive and significant $(\beta=0.74 ; p$-value $<0.001)$, which leads to support $\mathrm{H} 2$. Other studies have analyzed this relationship by applying the $t$-test and have reached the same conclusion. In Indonesia, Dewi and Hoesada (2020) and Dewi et al. (2019) based on a sample of 40 employees of Satuan Kerja Perangkat Daerah (SKPD) of West Jakarta Administration and 161 employees of South Sumatra Province Government Agency (Dinas), respectively, verified the existence of a positive and significant relationship between both variables. Same evidence was also obtained in the study by Majid et al. (2020) and Phornlaphatrachakorn (2019), when they have analyzed 12 Coffee Shop managers in Makassar city and 126 canned and processed food companies in Thailand, respectively.

Regarding the relationship between quality of ICS and quality of NFI, the results show no significant relationship between both variables ( $p$-value $>0.05)$, which does not allow one to give statistical support to H3. The results of this study contradict the results obtained by Bauer et al. (2018), as it was found that the quality of ICS contributes positively to the quality of NFI when prepared according to the Global Reporting Initiative (GRI) standards, and the results of Frazer (2020), since these authors conclude that ICS reinforces the assurance process, which contributes to the credibility and authenticity of the FI and NFI.

Quality of AIS shows a positive and significant effect on quality of FI ( $\beta=0.158$; $p$-value $<0.01)$. Hence, $\mathrm{H} 4$ is supported. The results are in line with the results obtained from Majid et al. (2020); Muda et al. (2018); Salehi et al. (2010). These authors, respectively, applied the study to 12 Coffee Shop managers in Makassar city, 112 employees of the Local Revenue Office in North Sumatera Province, Indonesia, and 489 financial managers of Iranian companies. Our results show that the quality of ICS and quality of AIS explain $69.7 \%$ of the quality of FI variance.

The results show that the quality of AIS has no direct and significant impact on quality of NFI ( $p$-value > 0.05), which leads to rejecting H5. The results contradict the studies of Petcharat and Mula (2009) and Zyznarska-Dworczak (2018), but they are in line with the evidence of Al-Wattar et al. (2019), who indicate that the current AIS does not fully meet the quality requirements of NFI reports.

The quality of FI has a positive and significant effect on the quality of NFI ( $\beta=0.759$; $p$-value $<0.001)$. Thus, H6 is supported and confirms the foundations presented by Martínez-Ferrero et al. (2013).

The results of this study show the absence of a significant relationship between the quality of FI and the DMS ( $p$-value $>0.05$ ). Therefore, H7 is not supported and contradicts the evidence mentioned by Menicucci (2020), since the author states that the FI, when complying with the quality requirements, are crucial in decision-making.

The results show that quality of NFI has a positive and significant effect on DMS ( $\beta=0.216 ; p$-value $<0.001)$. Hence, H8 is supported and meets the foundations presented by (Boulianne 2007; Barker and Eccles 2018; Pizzi 2018; Mbabazise et al. 2015), who mention that NFI plays an important role in decision-making in private companies: $92 \%$ of companies classify the NFI role in analysing market share trends; $57 \%$ indicate that they are important in the environment management; $42 \%$ in the new products development; 
$75 \%$ in employee management; $83 \%$ in customer management and $83 \%$ in compliance with government policies.

Quality of AIS has no direct and significant impact on DMS ( $p$-value $>0.05$ ). Thus, H9 is rejected. However, Sajady et al. (2008), who analyzed 347 financial managers of companies listed on the Tehran Stock Exchange, Iran, conclude that quality of AIS improves decision-making. Ibrahim et al. (2020) and Nguyen and Nguyen (2020) also defend that quality of AIS as contributing positively to the DMS.

The results show that quality of ICS has a positive and significant effect on DMS ( $\beta=0.654$ and $p$-value $<0.001$ ), supporting H10., a result which is also verified by Phornlaphatrachakorn (2019).

It is verified that DMS has a positive effect on Financial Performance and on NonFinancial Performance ( $\beta=0.541$ and $\beta=0.498$ ), with $p$-value $<0.001$, thus supporting H11 and H12. The same (evidence) is also found in the studies by Bosworth (2005), Patel (2015), Pravitasari (2018), Phornlaphatrachakorn (2019), Wauchope et al. (1992) and Zhang (2014).

Finally, the results show that the model variables explain about $30 \%$ and $t 70 \%$ of the Financial Performance and Non-Financial Performance variance, respectively. However, according to (Ayu et al. 2020), the ICS and AIS explain 17.1\% of companies' performance.

In Table 6, we summarize the empirical evidence of the proposed models and compare it with other studies in literature.

Table 6. Comparing results and literature.

\begin{tabular}{|c|c|c|}
\hline Hypotheses & Results & Literature \\
\hline $\begin{array}{l}\text { H1: The quality of ICS has a positive impact on the quality } \\
\text { of AIS. }\end{array}$ & Accepted & $\begin{array}{l}\text { Supported by Susanto (2016) and } \\
\text { Anggadini (2015) }\end{array}$ \\
\hline $\begin{array}{l}\text { H2: The quality of AIS has a positive impact on the quality } \\
\text { of FI. }\end{array}$ & Accepted & $\begin{array}{l}\text { Supported by Dewi and Hoesada (2020), } \\
\text { Dewi et al. (2019), } \\
\text { Satuan Kerja Perangkat Daerah (SKPD) and } \\
\text { Majid et al. (2020) } \\
\text { Phornlaphatrachakorn (2019) }\end{array}$ \\
\hline $\begin{array}{l}\text { H3: The quality of ICS has a positive impact on the quality } \\
\text { of NFI. }\end{array}$ & Rejected & Contradiction with Bauer et al. (2018) and Frazer (2020) \\
\hline $\begin{array}{l}\text { H4: The quality of AIS has a positive impact on the quality } \\
\text { of FI. }\end{array}$ & Accepted & $\begin{array}{l}\text { Supported by Majid et al. (2020); Muda et al. (2018); and Salehi } \\
\text { et al. (2010). }\end{array}$ \\
\hline $\begin{array}{l}\text { H5: The quality of AIS has a positive impact on the quality } \\
\text { of NFI. }\end{array}$ & Rejected & $\begin{array}{l}\text { Contradiction with Petcharat and Mula (2009) and } \\
\text { Zyznarska-Dworczak (2018). } \\
\text { Suported by Al-Wattar et al. (2019) }\end{array}$ \\
\hline $\begin{array}{l}\text { H6: The quality of FI has a positive impact on the quality } \\
\text { of NFI. }\end{array}$ & Accepted & Supported by Martínez-Ferrero et al. (2013) \\
\hline H7: The quality of FI has a positive impact on DMS. & Rejected & Contradiction with Menicucci (2020) \\
\hline H8: The quality of NFI has a positive impact on DMS. & Accepted & $\begin{array}{l}\text { Supported by Boulianne (2007); Barker and Eccles (2018); } \\
\text { Mbabazise et al. (2015); and Pizzi (2018). }\end{array}$ \\
\hline H9: The quality of AIS contributes positively to DMS. & Rejected & $\begin{array}{l}\text { Contradiction with Sajady et al. (2008); Ibrahim et al. (2020) } \\
\text { and Nguyen and Nguyen (2020) }\end{array}$ \\
\hline H10: the quality of ICS contributes positively to DMS. & Accepted & Supported by Phornlaphatrachakorn (2019) \\
\hline H11: DMS contributes positively to Financial Performance. & Accepted & $\begin{array}{l}\text { Supported by Bosworth (2005); Patel (2015); Pravitasari (2018); } \\
\text { Phornlaphatrachakorn (2019); Wauchope et al. (1992); and } \\
\text { Zhang (2014). }\end{array}$ \\
\hline $\begin{array}{l}\text { H12: DMS contributes positively to } \\
\text { Non-Financial Information. }\end{array}$ & Accepted & $\begin{array}{l}\text { Supported by Bosworth (2005); Patel (2015); Pravitasari (2018); } \\
\text { Phornlaphatrachakorn (2019); Wauchope et al. (1992); and } \\
\text { Zhang (2014). }\end{array}$ \\
\hline $\begin{array}{l}\text { H13: Financial Performance contributes positively to } \\
\text { Non-Financial Information. }\end{array}$ & Accepted & Supported by (Ayu et al. 2020 ) \\
\hline
\end{tabular}

As we can see from the table above, we confirm ten of the hypotheses. All of them with strong support in literature. 


\section{Conclusions}

Since February 2018, the number of new companies in Portugal has been higher than the number of companies entering insolvency proceedings (INE, Instituto Nacional de Estatística 2020). However, the significant number of insolvencies is worrying and has an impact on the country's economy development level.

The increase in global competitiveness stimulates the use of strategies that lead companies to a superior performance (Indrani et al. 2020). In this regard, highlighted is the important role that Information and Communication Technologies (ICT) can play in terms of resource management and decision-making (Rouissi 2020). Although ICT and information system are not new (Ibrahim et al. 2020), the quality of AIS and ICS can contribute to the quality of financial and non-financial information which is considered in their decision making, and these variables are determinant on DMS and on company' performance (Phornlaphatrachakorn 2019; Soudani 2012; Patel 2015).

The literature suggests the development of studies aimed at identifying the factors that contribute to companies' survival and growth (Bertolami et al. 2018). In this context, the main objective of this study is to analyze the factors (quality of ICS, quality of AIS, quality of FI, and quality of NFI) that influence DMS and Portuguese companies' performance. Based on a sample of 381 Portuguese companies, it was possible to answer the seven objectives defined in this research.

Regarding the first objective, which is aimed to analyze the influence of quality of ICS on quality of AIS, the results show that there is a positive and significant relationship between quality of ICS and quality of AIS, and that the first variable explains $28.4 \%$ of the variance of the second variable. The results support the first research hypothesis (H1) and are in line with those obtained in the studies by (Anggadini 2015; Hla and Teru 2015; Mndzebele 2012; Susanto 2016).

As for the second research objective, which aims to analyze the impact of quality of ICS on quality of FI (H2) and quality of NFI (H3), the results show that there is a significant and positive impact on quality of FI and absence of significant impact on quality of NFI, which allows supporting $\mathrm{H} 2$ and rejecting $\mathrm{H} 3$. Thus, the results are in line with the studies carried out by (Feng et al. 2009; Hendri and Amelia 2019; Dewi et al. 2019; Moreno-Enguix et al. 2019; Phornlaphatrachakorn 2019; Dewi and Hoesada 2020), as they also found a significant relationship between quality of ICS and quality of FI. Regarding the relationship between quality of ICS and quality of NFI, the results contradict those obtained in the investigation developed by Herz et al. (2017); Bauer et al. (2018); Bozzolan and Miihkinen (2019); Frazer (Frazer 2020); Gal and Akisik (2020). However, it is verified in this study that the quality of ICS influences quality of NFI, through quality of FI. The second objective also intends to analyze the impact of quality of AIS on quality of FI (H4) and on quality of NFI (H5). The results indicate that there is significant and positive impact on the quality of FI and absence of significant impact on the quality of NFI, which allows supporting $\mathrm{H} 4$ and rejecting $\mathrm{H} 5$. Thus, the results are in line with the results obtained by Sajady et al. (2008); Salehi et al. (2010); Zeina et al. (2016); Muda et al. (2018), but contradict the results obtained by Arroyo and HEC Montreal (2008); Petcharat and Mula (2009); Zyznarska-Dworczak (2018); Al-Wattar et al. (2019). However, the quality of ICS presents a positive and significant impact on the quality of FI through the quality of AIS. The results indicate that, both quality of ICS and quality of AIS have a positive and significant direct impact on quality of FI and explain $69.7 \%$ of its variance.

As regards the third objective, which is based on the assessment of quality of FI impact on quality of NFI, the results show the existence of a positive and significant relationship between these two constructs, providing statistical support to H6. The results are in line with the foundations presented by Martínez-Ferrero et al. (2013). In this study, it is verified that quality of ICS, quality of AIS, quality of FI explain $57.6 \%$ of the quality of NFI variance.

Regarding the fourth objective, which aims to analyze the impact of quality of FI and quality of NFI on DMS, the results show that there is no significant impact of quality of FI on DMS (H7); however, there is a positive and significant impact of quality of NFI on DMS 
(H8). Thus, $\mathrm{H7}$ is rejected and $\mathrm{H} 8$ is supported. Although the results show no significant relation in the relationship between quality of FI on DMS, Ježovita (2015); Menicucci (2020); Dewi et al. (2019); Malo-Alain et al. (2019) have found distinct evidence. However, the same results are verified by Boulianne (2007); Mbabazise et al. (2015); Barker and Eccles (2018) regarding the relationship between quality of NFI on DMS.

The fifth objective consists in analysing if the quality of AIS and the quality of ICS directly influence the DMS of Portuguese companies (H9 and H10, respectively). In this study, it is verified that the quality of AIS does not contribute significantly to the DMS, while the quality of ICS presents itself as a predictive variable of the DMS. Thus, H9 is rejected and H10 is supported. The same results are not evidenced in the studies of Sajady et al. (2008); Ibrahim et al. (2020); Nguyen and Nguyen (2020), but are supported by Feng et al. (2009); Han (2019); Phornlaphatrachakorn (2019). It should be noted that the results indicate that $65 \%$ of the DMS variance is determined by the variables quality of ICS, quality of AIS, quality of quality of FI, and quality of NFI.

The penultimate objective of this study consists in analysing whether the DMS contributes positively to the business performance (Financial Performance and Non-Financial Performance). The results show evidence that the DMS has a significant and positive impact on the Financial Performance and Non-Financial Performance, thus supporting $\mathrm{H} 11$ and H12, respectively. Therefore, the results are in line with the results obtained in the studies of (Harding 1998; Bosworth 2005; Zhang 2014; Patel 2015; Pravitasari 2018; Phornlaphatrachakorn 2019).

Regarding the last objective of this investigation, which aims to find out whether Financial Performance positively contributes to the Non-Financial Performance of Portuguese companies, the results show that Financial Performance has a positive and significant impact on Non-Financial Performance. Thus, the last hypothesis formulated in this study (H13) is supported. The results are in line with the evidence of Chen et al. (2018).

It should be noted that, in this study, the variables explain around $30 \%$ and $70 \%$ of the Financial Performance and Non-Financial Performance, respectively.

The literature review allowed one to identify two gaps. The first one relates to the absence of studies assessing the DMS and companies' perfomance determinants in an extensive way, thus contributing to the literature development. The second gap is related to the scarcity of studies in this area in Portugal. Thus, in practical terms, this investigation proves to be important for the Portuguese companies' managers, because it provides a better understanding of the factors that positively contribute to the DMS and Portuguese companies' performance.

The use of a convenience and non-probabilistic sample limits the generalization of the results (Etikan et al. 2016). Another verified limitation is that, although the email is addressed to managers, there is no guarantee that other people did not filled the questionnaires, although it had been asked to confirm the position they hold in the entity. On the other hand, as the questionnaire was developed in the Portuguese language, it excluded respondents who does not feel comfortable with the Portuguese language. Thus, two versions (Portuguese and English versions) should have been developed so that all those contacted could participate in this study.

In future investigations, we suggest: (1) the utility of financial information variable to be added to the model, since it is presented in the literature as a determinant variable on DMS (Phornlaphatrachakorn 2019); (2) a study examining whether there are differences in managers' perceptions due to their individual characteristics (age, gender, education, work experience), as these may influence the DMS (Ratcliff et al. 2009; Delazer et al. 2011; Shahsavarani et al. 2015) and consequently the companies' performance; (3) the application of the study to accountants and auditors, as they are the ones who prepare and verify business information, respectively; and (4) to the other countries, in order to make it possible to compare results in similar contexts, despite the inherent differences of each country. 
Author Contributions: Conceptualization, A.P.M. and J.V.; data curation, A.P.M. and J.V.; formal analysis, A.P.M., J.V. and A.S.; investigation, A.P.M. and J.V.; methodology, A.P.M. and J.V.; project administration, A.P.M.; resources, A.P.M. and J.V.; software, A.P.M. and J.V.; supervision, A.P.M.; validation, A.P.M., J.V. and A.S.; visualization, A.P.M. and A.S.; writing-original draft, A.P.M., J.V. and A.S.; writing-review and editing, A.P.M. and A.S. All authors have read and agreed to the published version of the manuscript.

Funding: This research received no external funding.

Conflicts of Interest: The authors declare no conflict of interest.

\section{Appendix A}

Table A1. Measurement Scales.

\begin{tabular}{|c|c|c|c|}
\hline Latent Variables & Code & Measurement & Source \\
\hline \multirow{7}{*}{ Quality of ICS } & 1QICS & $\begin{array}{l}\text { Internal control system has improved and promoted the company's } \\
\text { operational efficiency and effectiveness. }\end{array}$ & Phornlaphatrachakorn (2019) \\
\hline & 2QICS & $\begin{array}{l}\text { Internal control system has allowed achieving firms' business targets, } \\
\text { goals, and objectives. }\end{array}$ & Phornlaphatrachakorn (2019) \\
\hline & 3QICS & $\begin{array}{l}\text { Internal control system has allowed building and creating effective } \\
\text { operations, activity, and business practices. }\end{array}$ & Phornlaphatrachakorn (2019) \\
\hline & $4 \mathrm{QICS}$ & $\begin{array}{l}\text { Internal control system has allowed the company to prepare financial } \\
\text { information with quality. }\end{array}$ & $\begin{array}{c}\text { Adapted from } \\
\text { Phornlaphatrachakorn (2019) }\end{array}$ \\
\hline & $5 \mathrm{QICS}$ & $\begin{array}{l}\text { Internal control system has allowed the company to prepare } \\
\text { non-financial information with quality. }\end{array}$ & $\begin{array}{c}\text { Adapted from } \\
\text { Phornlaphatrachakorn (2019) }\end{array}$ \\
\hline & 6QICS & $\begin{array}{l}\text { The company complies with all required regulations, i.e., laws, rules, } \\
\text { guidelines, standards, and other related issues within internal } \\
\text { control quality. }\end{array}$ & Phornlaphatrachakorn (2019) \\
\hline & 7QICS & The company's internal control system has quality. & Pre-test \\
\hline \multirow{9}{*}{ Quality of AIS } & 1QAIS & $\begin{array}{l}\text { The automated data collection sped up the process to generate } \\
\text { financial statements. }\end{array}$ & Adaptet from Soudani (2012) \\
\hline & 2QAIS & $\begin{array}{l}\text { The current accounting information system has improved the quality of } \\
\text { non-financial reporting. }\end{array}$ & Adaptadet from Soudani (2012) \\
\hline & 3QAIS & $\begin{array}{l}\text { Accounting information system has contributed to the integrity of the } \\
\text { financial information reporting process. }\end{array}$ & Adaptet from Soudani (2012) \\
\hline & 4QAIS & $\begin{array}{l}\text { The accounting information system has contributed to the integrity of } \\
\text { the non-financial information reporting process. }\end{array}$ & Adaptet from Soudani (2012) \\
\hline & 5QAIS & $\begin{array}{l}\text { The data processing caused the improvement of the quality of the } \\
\text { financial reports. }\end{array}$ & Adaptet from Soudani (2012) \\
\hline & 6QAIS & $\begin{array}{l}\text { The automated data collection sped up the process of non-financil } \\
\text { information preparation }\end{array}$ & Adaptadet from Soudani (2012) \\
\hline & 7QAIS & $\begin{array}{l}\text { The automated data collection sped up the process to generate financial } \\
\text { statements and overcome human weaknesses in data processing. }\end{array}$ & Adaptet from Soudani (2012) \\
\hline & 8QAIS & $\begin{array}{l}\text { The automated data collection provides a platform with access to } \\
\text { information, which facilitates the use of it. }\end{array}$ & $\begin{array}{l}\text { Adaptet from Kpurugbara et al. } \\
\qquad(2016)\end{array}$ \\
\hline & 9QAIS & $\begin{array}{c}\text { The company's accounting information system works efficiently } \\
\text { and effectively. }\end{array}$ & Pre-test \\
\hline
\end{tabular}


Table A1. Cont.

\begin{tabular}{|c|c|c|c|}
\hline Latent Variables & Code & Measurement & Source \\
\hline \multirow{9}{*}{ Quality of FI } & 1QFI & $\begin{array}{l}\text { The company is distinguished by its accuracy in presenting users' needs } \\
\text { of financial data. }\end{array}$ & Dornier (2018) \\
\hline & 2QFI & The accuracy of financial information helps decision-making. & Dornier (2018) \\
\hline & 3QFI & Financial information is carefully prepared to ensure its reliability & Adapted from Dornier (2018) \\
\hline & $4 \mathrm{QFI}$ & $\begin{array}{l}\text { The provided financial data are consistent with the users' needs in } \\
\text { different financial periods per year }\end{array}$ & Dornier (2018) \\
\hline & $5 \mathrm{QFI}$ & Financial information is easily understood by its user. & Dornier (2018) \\
\hline & 6QFI & $\begin{array}{l}\text { Financial information is inclusive for all the financial aspects that users } \\
\text { need in the decision-making process. }\end{array}$ & Dornier (2018) \\
\hline & 7QFI & $\begin{array}{l}\text { Financial information is provided in an appropriate time so they reach } \\
\text { the decision maker before losing their ability to influence the } \\
\text { taken decision. }\end{array}$ & Dornier (2018) \\
\hline & 8QFI & $\begin{array}{l}\text { Financial information represents in a reliable way what you want } \\
\text { to portray. }\end{array}$ & Pre-test \\
\hline & 9QFI & Financial information is free of value judgments. & Pre-test \\
\hline \multirow{5}{*}{ Quality of NFI } & 1QNFI & The accuracy of non-financial information helps decision-making. & Adapted from Dornier (2018) \\
\hline & 2QNFI & Non-financial information is carefully prepared to ensure its quality & Adapted from Dornier (2018) \\
\hline & 3QNFI & Non-financial information is easily understood by its user. & Adapted from Dornier (2018) \\
\hline & 4QNFI & $\begin{array}{l}\text { Non-financial information includes all the information necessary to } \\
\text { make decisions. }\end{array}$ & Adapted from Dornier (2018) \\
\hline & 5QNFI & Non-financial information is free of value judgements. & Pre-test \\
\hline \multirow{5}{*}{$\begin{array}{l}\text { Decision Making } \\
\text { Success }\end{array}$} & 1DMS & $\begin{array}{l}\text { The decisions made allowed the company to achieve advantages in } \\
\text { terms of operations, management and performance }\end{array}$ & Phornlaphatrachakorn (2019) \\
\hline & 2DMS & $\begin{array}{l}\text { Decisions made about investments took into account different } \\
\text { alternatives or options, which allowed the company to choose the } \\
\text { best solution. }\end{array}$ & Phornlaphatrachakorn (2019) \\
\hline & 3DMS & $\begin{array}{l}\text { Decisions made about future operations based on best practices/trends } \\
\text { in doing business over the long term have contributed to } \\
\text { better performance. }\end{array}$ & $\begin{array}{l}\text { Adapted from } \\
\text { Phornlaphatrachakorn (2019) }\end{array}$ \\
\hline & 4DMS & $\begin{array}{l}\text { The decisions taken have contributed to maximized operational } \\
\text { efficiency and effectiveness. }\end{array}$ & Phornlaphatrachakorn (2019) \\
\hline & 5DMS & The decisions made in the company determine its success. & Pre-test \\
\hline Performance & & In the last 5 years & \\
\hline \multirow{8}{*}{$\begin{array}{c}\text { Financial } \\
\text { Performance }\end{array}$} & $1 \mathrm{FP}$ & The company's turnover has increased & Trailer et al. (1996) \\
\hline & $2 \mathrm{FP}$ & The size of the company has increased. & Trailer et al. (1996) \\
\hline & $3 \mathrm{FP}$ & The number of the company's employees increased & Trailer et al. (1996) \\
\hline & $4 \mathrm{FP}$ & The company's operating profit has improved/increased & Trailer et al. (1996); Soudani (2012) \\
\hline & $5 \mathrm{FP}$ & $\begin{array}{l}\text { The company's return on asset has improved/increased } \\
\text { (EBIT/Total Assets). }\end{array}$ & $\begin{array}{l}\text { Trailer et al. (1996); adapted from } \\
\text { Soudani (2012) }\end{array}$ \\
\hline & $6 \mathrm{FP}$ & Return on equity improved/increased (EBIT/Equity). & $\begin{array}{l}\text { Trailer et al. (1996); adapted from } \\
\text { Soudani (2012) }\end{array}$ \\
\hline & 7FP & Profitability on sales increased (EBIT/Sales). & Adapted from Soudani (2012) \\
\hline & $8 \mathrm{FP}$ & The company's financial performance has been successful. & Pre-test \\
\hline
\end{tabular}


Table A1. Cont.

\begin{tabular}{|c|c|c|c|}
\hline Latent Variables & Code & Measurement & Source \\
\hline \multirow{7}{*}{$\begin{array}{l}\text { Non-Financial } \\
\text { Performance }\end{array}$} & 9NFP & The company has improved its customer service & Adapted from Soudani (2012) \\
\hline & $10 \mathrm{NFP}$ & $\begin{array}{l}\text { The company has improved working conditions, regardless of the } \\
\text { employee's position. }\end{array}$ & Adapted from Soudani (2012) \\
\hline & $11 \mathrm{NFP}$ & $\begin{array}{l}\text { The company has improved its performance in terms of social } \\
\text { responsibility (voluntary effort on the part of the company in the } \\
\text { creation of various measures to meet the expectations of the different } \\
\text { interested parties-stakeholders). }\end{array}$ & Adapted from Soudani (2012) \\
\hline & 12NFP & The company achieved improvements in customer satisfaction. & Adapted from Soudani (2012) \\
\hline & $13 \mathrm{NFP}$ & The company has increased its employee retention rates. & Adapted from Soudani (2012) \\
\hline & $14 \mathrm{NFP}$ & The company has increased its customer retention rates. & Adapted from Soudani (2012) \\
\hline & $15 \mathrm{NFP}$ & The company's (non-financial) performance has been successful. & Pre-test \\
\hline
\end{tabular}

Legend: QICS—Quality of ICS; QAIS—Quality of AIS; QFI—Quality of FI; QNFI—Quality of NFI; DMS—Decision Making Decision; FP-Financial Performance; NFP-Non-Financial Performance.

\section{References}

Al-Wattar, Yasir Mohammed Ali, Akeel Hamza Almagtome, and Karrar Mohammed Al-Shafeay. 2019. The Role of Integrating Hotel Sustainability Reporting Practices into an Accounting Information System to Enhance Hotel Financial Performance: Evidence from Iraq. African Journal of Hospitality, Tourism and Leisure 8: 1-6.

Anggadini, Sri Dewi. 2015. The Effect of Top Management Support and Internal Control of the Accounting Information Systems Quality and Its Implications on the Accounting Information Quality. Information Management and Business Review 7: 93-102. [CrossRef]

Anh, Tu Chuc, Lan Huong Tran Thi, Huy Pham Quang, and Thuy Truong Thi. 2020. Factors Influencing the Effectiveness of Internal Control in Cement Manufacturing Companies. Management Science Letters 10: 133-42. [CrossRef]

Arroyo, Paulina, and HEC Montreal. 2008. The Three Dimensions of a Sustainable Management Accounting System. ASAC 29: 23-39.

Asare, Stephen Kwaku, and Arnold Wright. 2012. The Effect of Type of Internal Control Report on Users' Confidence in the Accompanying Financial Statement Audit Report. Contemporary Accounting Research 29: 152-75. [CrossRef]

Ayu, Putu, Yohana Putri, Dan I. Dewa, and Made Endiana. 2020. Pengaruh Sistem Informasi Akuntansi Dan Sistem Pengendalian Internal Terhadap Kinerja Perusahaan (Studi Kasus Pada Koperasi Di Kecamatan Payangan). License Jurnal KRISNA: Kumpulan Riset Akuntansi 11: 179-89. [CrossRef]

Azizi Ismail, Noor, and Malcolm King. 2007. Factors Influencing the Alignment of Accounting Information Systems in Small and Medium Sized Malaysian Manufacturing Firms. Journal of Information Systems and Small Business Ismail E King 1: 1-20. Available online: https: / / ojs.deakin.edu.au/index.php/jissb/article/view/1 (accessed on 1 June 2021).

Barker, Richard, and Robert G. Eccles. 2018. Should FASB and IASB Be Responsible for Setting Standards for Nonfinancial Information? SSRN Electronic Journal. [CrossRef]

Bauer, Andrew M., Darren Henderson, and Daniel P. Lynch. 2018. Supplier Internal Control Quality and the Duration of CustomerSupplier Relationships. The Accounting Review 93: 59-82. [CrossRef]

Baugh, Matthew, Matthew S. Ege, and Christopher G. Yust. 2021. Internal Control Quality and Bank Risk-Taking and Performance. AUDITING: A Journal of Practice \& Theory 40: 49-84. [CrossRef]

Baumgartner, Hand, and Christian Homburg. 1996. Applications of structural equation modeling in marketing and consumer research: A review. International Journal of Research in Marketing 13: 139-161. [CrossRef]

Bennett, Martin, Peter James, and Leon Klinkers. 2017. Sustainable Measures_Evaluation and Reporting of Environmental and Social Performance. London and New York: Routledge; Taylor \& Francis Group. [CrossRef]

Bertolami, Mariana, Rinaldo Artes, Pedro João Gonçalves, Marcos Hashimoto, and Sergio Giovanetti Lazzarini. 2018. Sobrevivência de Empresas Nascentes: Influência Do Capital Humano, Social, Práticas Gerenciais e Gênero. Revista de Administração Contemporânea 22: 311-35. [CrossRef]

Bosworth, Derek L. 2005. Determinants of Enterprise Performance. Available online: https://www.google.com/books?hl=en\& lr=\&id=x-91bjvD7QQC\&oi=fnd\&pg=PR9\&dq=Bosworth, +D.+L.+(2005).+Determinants+of+enterprise+performance.+In+ Marco+Andre+da+Silva+Costa, +Abdelhamid+Nedzhad,+Danijela+Lucic.+Economic+and+Social+Development.+Book + of + Proceedings + of $+68+$ th + International + Scientific + Conference + on + Economic + and + Social + Deve\&ots=pCkPE6BFnf $\& s i g=$ ZVVzAFOj3bLZPbU2zK5hPAQcTmA (accessed on 1 June 2021).

Boulianne, Emilio. 2007. Revisiting Fit between AIS Design and Performance with the Analyzer Strategic-Type. International Journal of Accounting Information Systems 8: 1-16. [CrossRef]

Bozzolan, Saverio, and Antti Miihkinen. 2019. The Quality of Mandatory Non-Financial (Risk) Disclosures: The Moderating Role of Audit Firm and Partner Characteristics. SSRN Electronic Journal. [CrossRef] 
Cepêda, Catarina, and Albertina Monteiro. 2020. The 'Accountant's Perception of the Usefulness of Financial Information in Decision Making-A Study in Portugal. Review of Business Management 22: 363-80. [CrossRef]

Chen, Yi Chun, Mingyi Hung, and Yongxiang Wang. 2018. The Effect of Mandatory CSR Disclosure on Firm Profitability and Social Externalities: Evidence from China. Journal of Accounting and Economics 65: 169-90. [CrossRef]

COSO. 2013. Internal Control-Integrated Framework: Executive Summary. Available online: https://www.coso.org/documents/99 0025p-executive-summary-final-may20.pdf (accessed on 1 June 2021).

Delazer, Margarete, Laura Zamarian, Elisabeth Bonatti, Nicola Walser, Giorgi Kuchukhidze, Thomas Bodner, Thomas Benke, Florian Koppelstaetter, and Eugen Trinka. 2011. Decision Making under Ambiguity in Temporal Lobe Epilepsy: Does the Location of the Underlying Structural Abnormality Matter? Epilepsy and Behavior 20: 34-37. [CrossRef]

Dewi, Ratmi, and Jan Hoesada. 2020. The Effect of Government Accounting Standards, Internal Control Systems, Competence of Human Resources, and Use of Information Technology on Quality of Financial Statements. International Journal of Innovative Research and Advanced Studies (IJIRAS) 7: 4-10. Available online: http://www.ijiras.com/2020/Vol_7-Issue_1/paper_2.pdf (accessed on 1 June 2021).

Dewi, Nur Fitri, S. M. Ferdous Azam, and Siti Khalidah Mohd Yusoff. 2019. Factors Influencing the Information Quality of Local Government Financial Statement and Financial Accountability. Management Science Letters 9: 1373-84. [CrossRef]

Dimitrijevic, Dragomir, Vesna Milovanovic, and Vladimir Stancic. 2015. University of Information Technology and Management in Rzeszów Financial Internet. Cejsh.Icm.Edu.Pl 11: 34-44. [CrossRef]

Do, Duc Tai, and Thi Thanh Long Dinh. 2020. Determinants Influencing the Quality of Accounting Service: The Case of Accounting Service Firms in Hanoi, Vietnam. Available online: http:/ / m.growingscience.com/beta/3480-determinants-influencing-thequality-of-accounting-service-the-case-of-accounting-service-firms-in-hanoi-vietnam.html (accessed on 1 June 2021).

Dornier, Pavlos. 2018. Investigating the Impact of Comprehensive Information Systems on Accounting Information Quality. Electronic Business Journal 17: 1-15. Available online: http:/ / electronic-businessjournal.com/images/2018/12/1-Investigating_the_Impact_ of_Comprehensive_Information_Systems_on_Accounting_Information_Quality.pdf (accessed on 1 June 2021).

Etikan, Ilker, Sulaiman Abubakar Musa, and Rukayya Sunusi Alkassim. 2016. Comparison of Convenience Sampling and Purposive Sampling. American Journal of Theoretical and Applied Statistics 5: 1-4. [CrossRef]

Fachada, Francisco José Cunha. 2014. Sistema de Controlo Interno Na Administração Central Do Estado: O Caso Dos Organismos Do Ministério Das Finanças. Coimbra: Universidade de Coimbra, Available online: https:/ / eg.uc.pt/handle/10316/27499 (accessed on 1 June 2021).

Feng, Mei, Chan Li, and Sarah McVay. 2009. Internal Control and Management Guidance. Journal of Accounting and Economics 48: 190-209. [CrossRef]

Fitriati, Azmi, and Azhar Susanto. 2017. The Accounting Information System Quality Improvement through Internal Control and Top Management Support Effectiveness. Journal of Theoretical and Applied Information Technology 95: 5003-11.

Flöstrand, Per. 2006. The Valuation Relevance of Non-financial Information. Management Research News 29: 580-97. [CrossRef]

Fornell, Claes, and David F. Larcker. 1981. Evaluating Structural Equation Models with Unobservable Variables and Measurement Error. Journal of Marketing Research 18: 39-50. [CrossRef]

Frazer, Linval. 2020. Does Internal Control Improve the Attestation Function and by Extension Assurance Services? A Practical Approach. Journal of Accounting and Finance 20: 28-38. [CrossRef]

Gal, Graham, and Orhan Akisik. 2020. The Impact of Internal Control, External Assurance, and Integrated Reports on Market Value. Corporate Social Responsibility and Environmental Management 27: 1227-40. [CrossRef]

Gomes, Emilia. 2014. A Importância Do Controlo Interno No Planeamento de Auditoria. Revisores e Auditores 64: 8-31.

Hair, Joseph F., Jr., Rolph E. Anderson, Ronald L. Tatham, and William C. Black. 1998. Multivariate Data Analysis, 5th ed. Upper Saddle River: Prentice Hall.

Han, Xi. 2019. Internal Control and Non-Efficiency Investment of Listed Companies. Paper presented at 4th International Social Sciences and Education Conference (ISSEC 2019), Xiamen, China, June 27-28; vol. 4, pp. 343-48. [CrossRef]

Harding, Ronnie. 1998. Environmental Decision-Making the Roles of Scientists, Engineers and the Public. Sydney: The Federation Press.

Hendri, and Sarah Amelia. 2019. The Influence of Human Resources, and Internal Control on the Quality of Financial Statement: Accounting Information System as a Moderating Role. International Journal of Management, Accounting and Economics 6: 761-69. Available online: www.ijmae.com (accessed on 1 June 2021).

Herz, Robert H., Brad J. Monterio, and Jeffrey C. Thomson. 2017. Leveraging the COSO Internal Control—Integrated Framework to Improve Confidence in Sustainability Performance Data. pp. 1-55. Available online: www.linkedin.com/in/bradmonterio (accessed on 1 June 2021).

Hla, Daw, and Susan Peter Teru. 2015. Efficiency of Accounting Information System and Performance Measures-Literature 'Review'. International Journal of Multidisciplinary and Current Research 3. Available online: http:/ /ijmcr.com (accessed on 1 June 2021).

Hussin, Husnayati, Malcolm King, and Paul Cragg. 2002. IT Alignment in Small 'Firms'. European Journal of Information Systems 11: 108-27. [CrossRef]

Ibrahim, Fahmi, Diyana Najwa Haji Ali, and Nur Suaidah Awang Besar. 2020. Accounting Information Systems (AIS) in SMEs: Towards an Integrated Framework. International Journal of Asian Business and Information Management 11: 51-67. [CrossRef] 
Indrani, M. W., Moonsamy Naidoo, and Guneratne Wickremasinghe. 2020. Exploring Adoption and Implementation of Strategic Management Tools and Techniques by Listed Companies in the Sri Lankan Context 12 2. International Journal of Accounting $\mathcal{E}$ Business Finance 6: 106-23. [CrossRef]

INE, Instituto Nacional de Estatística. 2020. Portal Do INE Portal. População Média Anual Residente (N. ${ }^{\circ}$ ) Por Local de Residência (NUTS), Sexo e Grupo Etário (Por Ciclos de Vida). Available online: https: / /www.ine.pt/xportal/xmain?xpid=INE\&xpgid=ine_ indicadores\&contecto=pi\&indOcorrCod=0008067\&selTab=tab0 (accessed on 1 June 2021).

Ježovita, Ana. 2015. Accounting Information in a Business Decision-Making Process-Evidence from Croatia. Zagreb International Review of Economics \& Business 18: 61-79. [CrossRef]

Ji, Xu-Dong, Wei Lu, and Wen Qu. 2017. Voluntary Disclosure of Internal Control Weakness and Earnings Quality: Evidence from China. The International Journal of Accounting 52: 27-44. [CrossRef]

Jokipii, Annukka. 2010. Determinants and Consequences of Internal Control in Firms: A Contingency Theory Based Analysis. Journal of Management and Governance 14: 115-44. [CrossRef]

Kaplan, David, Ramayya Krishnan, Rema Padman, and James Peters. 1998. Assessing Data Quality in Accounting Information Systems. Communications of the ACM 41: 72-78. [CrossRef]

Kpurugbara, Nwinee, Yikarebogha Erorogha Akpos, Vincent G. Nwiduuduu, and Ibinabo Tams-Wariboko. 2016. Impact of Accounting Information System on Organizational Effectiveness-A Study of Selected Small and Medium Scale Enterprises in Woji, Portharcourt. Internaltional Journal of Research 3: 974-82.

Le, Thi Tam, Thi Mai Anh Nguyen, and Thi Thu Hien Phan. 2019. Environmental Management Accounting and Performance Efficiency in the Vietnamese Construction Material Industry-a Managerial Implication for Sustainable Development. Sustainability 11: 5152. [CrossRef]

Leiwakabessy, Theophilia Fina Febrione. 2020. The Effect of Government Internalal Control System, Human Resource Competency, and Accounting Information Systems to the Quality of the Local Government. Jurnal Sosial Humaniora 11. Available online: http: / / ojs.unida.ac.id/JSH/article/view/3066 (accessed on 1 June 2021).

Li, Chan, Gary F. Peters, Vernon J. Richardson, and Marcia Weidenmier Watson. 2012. The Consequences of Information Technology Control Weaknesses on Management Information Systems: The Case of Sarbanes-Oxley Internal Control Reports. MIS Quarterly: Management Information Systems 36: 179-204. [CrossRef]

Majid, Jamaluddin, Memen Suwandi, Lince Bulutoding, and Andi Wawo Sumarlin. 2020. The Influence of Accounting Information Systems and Internal Control on the Quality of Financial Statement with Intellectual Intelligence as a Moderating Variable (a Study on Coffee Shops in Makassar City). International Journal of Research Science E Management 7. Available online: http: / / repositori.uin-alauddin.ac.id/18228/ (accessed on 1 June 2021).

Malo-Alain, Alaa Mohamad, Magdy Melegy Abdul Hakim Melegy, and Mahmoud Ragab Yassein Ghoneim. 2019. The Effects of Sustainability Disclosure on the Quality of Financial Reports in Saudi Business Environment. Academy of Accounting and Financial Studies Journal 23: 1-12.

Marôco, João. 2010. Análise de Equações Estruturais: Fundamentos Teóricos, Software \& Aplicações. Available online: https: / / www.google.com/books?hl=en\&lr=\&id=oYK1MG8tc3UC\&oi=fnd\&pg=PR9\&dq=Mar\{ô $\}$ co, + J.+(2010).+An $\{\{a ́\}\} l i s e+$ de+Equaç\{ o\}es+Estruturais+-+Fundamentos+te\{ó $\}$ ricos, +Software+e+Aplicaç\{\{ o $\}\}$ es.+ReportNumber.\&ots=0m-_I86j9D\& sig=BXFFKxOaH8pOt7_XKkUlRMHhR-4 (accessed on 1 June 2021).

Martínez-Ferrero, Jennifer, Isabel M. Garcia-Sanchez, and Beatriz Cuadrado-Ballesteros. 2013. Effect of Financial Reporting Quality on Sustainability Information Disclosure. Wiley Online Library 22: 45-64. [CrossRef]

Martos, A., R. Pacheco-Torres, J. Ordóñez, and E. Jadraque-Gago. 2016. Towards Successful Environmental Performance of Sustainable Cities: Intervening Sectors. A Review. Renewable and Sustainable Energy Reviews 57: 479-95. [CrossRef]

Mbabazise, Mbabazi, Twesige Daniel, Mazimpaka Claude, and Jaya Shukla. 2015. Reporting of Non-Financial Information and Its Impact on the Decisions Taken in Private Institutions in Rwanda: Case Study Norhern Province. International Journal of Small Business and Entrepreneurship Research 2: 57-71. Available online: www.eajournals.org (accessed on 1 June 2021).

Menicucci, Elisa. 2020. Earnings Quality. Earnings Quality: Definitions, Measures, and Financial Reporting. Cham: Springer International Publishing. [CrossRef]

Mirnenko, Volodymyr I., Ivan M. Tkach, Maryna V. Potetiuieva, Mykhaylo Yu. Mechetenko, Mykola Ya Tkach, and Olena Holota. 2020. Analysis of Approaches to Assessing Effectiveness of the System of Internal Control of the Military Organization as the Element of Public Internal Financial. Espacios 41: 14-20. Available online: http://www.revistaespacios.com/a20v41n08/20410814.html (accessed on 1 June 2021).

Mndzebele, Nomsa. 2012. The Usage of Accounting Information Systems for Effective Internal Controls in the Hotels. International Journal of Advanced Computer Technology 2. Available online: https://www.ijact.org/ijactold/volume2issue5/IJ0250003.pdf (accessed on 1 June 2021).

Mohammed Al-Shafeay, Karrar, and Akeel Almagtome. 2019. The Role of Integrating Hotel Sustainability Reporting Practices into an Accounting Information System to Enhance Hotel Financial Performance: Evidence from Iraq. Researchgate.Net. Available online: https: / / www.researchgate.net/publication/336778683 (accessed on 1 June 2021).

Montenegro, Tânia Menezes, and Lúcia Lima Rodrigues. 2020. Determinants of the Attitudes of Portuguese Accounting Students and Professionals towards Earnings Management. Journal of Academic Ethics 18: 301-32. [CrossRef] 
Moreno-Enguix, María del Rocío, Ester Gras-Gil, and Joaquín Henández-Fernández. 2019. Relation between Internet Financial Information Disclosure and Internal Control in Spanish Local Governments. Aslib Journal of Information Management 71: 176-94. [CrossRef]

Muda, Iskandar, Abdul Haris Harahap, Syafruddin Ginting, Azhar Maksum, and Erwin Abubakar. 2018. Factors of Quality of Financial Report of Local Government in Indonesia. IOP Conference Series: Earth and Environmental Science 126: 1-6. [CrossRef]

Napitupulu, Ilham Hidayah. 2018. Organizational Culture in Management Accounting Information System: Survey on State-Owned Enterprises (SOEs) Indonesia. Article Global Business Review 19: 1-16. [CrossRef]

Nguyen, Hieu Thanh, and Anh Huu Nguyen. 2020. Determinants of Accounting Information Systems Quality: Empirical Evidence from Vietnam. Accounting 6: 185-98. [CrossRef]

Patel, B. 2015. Effects of Accounting Information System on Organizational Profitability. International Journal of Research and Analytical Reviews 2: 72-76.

Petcharat, Nickie, and Joseph M. Mula. 2009. Identifying System Characteristics for Development of a Sustainability Management Accounting Information System: Towards a Conceptual Design for the Manufacturing Industry. Paper presented at 2009 Fourth International Conference on Cooperation and Promotion of Information Resources in Science and Technology, Beijing, China, November 21-23; pp. 56-64. [CrossRef]

Phornlaphatrachakorn, Kornchai. 2019. Internal Control Quality, Accounting Information Usefulness, Regulation Compliance, and Decision-Making Success: Evidence from Canned and Processed Foods Businesses in Thailand. International Journal of Business 24: 198-215. Available online: https:/ / www.craig.csufresno.edu/ijb/Volumes/Volume24/V24N2-5.pdf (accessed on 1 June 2021).

Ping, Robert A. 2004. On assuring valid measures for theoretical models using survey data. Journal of Business Research 57: 125-41. [CrossRef]

Pizzi, Simone. 2018. The Relationship between non-financial reporting, environmental strategies and financial performance. empirical evidence from Milano stock exchange. Administrative Sciences 8: 76. [CrossRef]

Pordata. 2019. Retrato de Portugal PORDATA, Edição 2019. Available online: https://www.pordata.pt/ebooks/PT2019v20190711/ mobile/index.html (accessed on 1 June 2021).

Pordata. 2020. Nascimentos, Mortes e Sobrevivência a 1 Ano de Empresas Não Financeiras. Available online: https://www.pordata.pt/ (accessed on 1 June 2021).

Pravitasari, Nirwana Putri. 2018. Effect of Accounting Information System For Internal Control «Sippuh Online» in Pt. Dwimajaya Utama. Russian Journal of Agricultural and Socio-Economic Sciences 80: 167-71. [CrossRef]

Rashedi, Hadi, and Toraj Dargahi. 2019. How Influence the Accounting Information Systems Quality of Internal Control on Financial Reporting Quality. Journal of Modern Developments in Management and Accounting 2: 33-45. Available online: http: / /jmdma.ir/index.php/JMDMA/article/view/40 (accessed on 1 June 2021).

Ratcliff, Roger, Marios G. Philiastides, and Paul Sajda. 2009. Quality of Evidence for Perceptual Decision Making Is Indexed by Trial-to-Trial Variability of the EEG. Proceedings of the National Academy of Sciences of the United States of America 106: 6539-44. [CrossRef]

Raucci, Domenico, Lara Tarquinio, Daniela Rupo, and Salvatore Loprevite. 2020. Non-Financial Performance Indicators: The Power of Measures to Operationalize the Law. In Sustainability and Law. Cham: Springer International Publishing, pp. 275-91. [CrossRef]

Rouissi, Chiraz. 2020. User Satisfaction and Information System: Case for an Emerging Country. Marketing and Management of Innovations 87-105. [CrossRef]

Sajady, Hussein, Mohsen Dastgir, and H. Hashem Nejad. 2008. Evaluation of the Effectiveness of Accounting Information Systems. International Journal of Information Science and Management 6: 49-59.

Salehi, Mahdi, Vahab Rostami, and Abdolkarim Mogadam. 2010. Usefulness of Accounting Information System in Emerging Economy: Empirical Evidence of Iran. International Journal of Economics and Finance 2. [CrossRef]

Sari, Maya. 2018. The Effect of the Government of Internal Control System on the Quality of Financial Statements in the Coal Regency Village Of-Fice. Accounting 134-44. Available online: http://proceedings.conference.unpas.ac.id/index.php/icis/article/view / 520 (accessed on 1 June 2021).

Schroeder, Joseph H., and Marcy L. Shepardson. 2016. Do SOX 404 Control Audits and Management Assessments Improve Overall Internal Control System Quality? Accounting Review 91: 1513-41. [CrossRef]

Schwartz, Mark S. 2016. Ethical Decision-Making Theory: An Integrated Approach. Journal of Business Ethics 139: 755-76. [CrossRef]

Shahsavarani, Amir Mohammad, Esfandiar Azad, and Marz Abadi. 2015. The Bases, Principles, and Methods of Decision-Making: A Review of Literature. International Journal of Medical Reviews Review Article International Journal of Medical Reviews 2. Available online: www.amazon.com (accessed on 1 June 2021).

Soudani, Siamak Nejadhosseini. 2012. The Usefulness of an Accounting Information System for Effective Organizational Performance. International Journal of Economics and Finance 4: 136-145. Available online: https://www.academia.edu/download/39214984/165 17-52549-1-SM.pdf (accessed on 1 June 2021). [CrossRef]

Steenkamp, Jan Benedict E. M., and Hans C. M. van Trijp. 1991. The Use of Lisrel in Validating Marketing Constructs. International Journal of Research in Marketing 8: 283-99. [CrossRef]

Susanto, Azhar. 2016. The Effect of Internal Control on Accounting Information System. International Business Management 10: 5523-29. [CrossRef] 
Trailer, Jeff W., Robert C. Hill, and Gregory B. Murphy. 1996. Measuring Performance in Entrepreneurship Research. Journal of Business Research 36: 15-23. [CrossRef]

Triono, BRM Suryo, and Septiana Novita Dewi. 2020. Pengaruh Sistem Pengendalian Intern Terhadap Kualitas Laporan Keuangan Pemerintah Daerah. Jurnal Akuntansi Dan Pajak 21. [CrossRef]

Verrecchia, Robert E. 1990. Information Quality and Discretionary Disclosure. Journal of Accounting and Economics 12: 365-80. [CrossRef]

Wali, Sonda, and Sana Mardessi Masmoudi. 2020. Internal Control and Real Earnings Management in the French Context. Journal of Financial Reporting and Accounting 18: 363-87. [CrossRef]

Wauchope, R. D., T. M. Buttler, A. G. Hornsby, P. W. M. Augustijn-Beckers, and J. P. Burt. 1992. The SCS/ARS/CES Pesticide Properties Database for Environmental Decision-Making. Reviews of Environmental Contamination and Toxicology. [CrossRef]

Zebua, Justika, Muhammad Rasuli, and Vera Oktari. 2020. Determinan Kualitas Laporan Keuangan Pemerintah Daerah: Studi Pada Opd Pemerintah Kota Pekanbaru. Jurnal Kajian Akuntansi Dan Bisnis Terkini 1: 170-83. Available online: www.cakaplah.com (accessed on 1 June 2021). [CrossRef]

Zeina, Nur, Maya Sari, and Djumhana Purwanegara. 2016. The Effect of Quality Accounting Information System in Indonesian Government (BUMD at Bandung Area) View Project Website View Project The Effect of Quality Accounting Information System in Indonesian Government (BUMD at Bandung Area). Research Journal of Finance and Accounting www.Iiste.Org ISSN 7. Available online: www.iiste.org (accessed on 1 June 2021).

Zeina, Nur, Maya Sari, Nunuy Nur Afifah, Azhar Susanto, and Memed Sueb. 2019. Quality Accounting Information Systems with 3 Important Factors in BUMN Bandung Indonesia. Atlantis-Press.Com. Available online: https://www.atlantis-press.com/article/ 125916454.pdf (accessed on 1 June 2021).

Zhang, Hao. 2014. A Framework for Integrating Systems Thinking into Sustainable Manufacturing. Available online: https: / / ir.library.oregonstate.edu/concern/graduate_thesis_or_dissertations / qz20sx98s (accessed on 1 June 2021).

Zyznarska-Dworczak, Beata. 2018. Legitimacy Theory in Management Accounting Research. Problemy Zarzadzania 16: 195-203. [CrossRef] 